\title{
Mini review: Transposable Elements in Cancer and other Human Diseases
}

\section{Benoît Chénais*}

Mer Molécules Santé EA2160, UFR Sciences et Techniques, Université du Maine, Le Mans, France.

*Corresponding Author: Chénais B., Mer Molécules Santé, UFR Sciences et Techniques, Université du Maine, Avenue Olivier Messiaen, F-72085 Le Mans Cedex, France, Tel:+33243-833-25; fax +33-243-833-917; Email: bchenais@univ-lemans.fr

\begin{abstract}
Transposable elements (TEs) are mobile DNA sequences representing a substantial fraction of most genomes. Through the creation of new genes and functions, TEs are important elements of genome plasticity and evolution. However TE insertion in human genomes may be the cause of genetic dysfunction and alteration of gene expression contributing to cancer and other human diseases. Besides the chromosome rearrangements induced by TE repeats, this mini-review shows how gene expression may be altered following TE insertion, for example by the creation of new polyadenylation sites, by the creation of new exons (exonization), by exon skipping and by other modification of alternative splicing, and also by the alteration of regulatory sequences. Through the correlation between TE mobility and the methylation status of DNA, the importance of chromatin regulation is evident in several diseases. Finally this overview ends with a brief presentation of the use of TEs as biotechnology tools for insertional mutagenesis screening and gene therapy with DNA transposons.
\end{abstract}

Keywords:alternative splicing; gene expression; gene therapy; human disease; promoter; recombination; retrotransposon; transposon 


\section{INTRODUCTION}

Transposable elements (TEs) are mobile DNA sequences representing a substantial fraction of most genomes (e.g. up to $85 \%$ of the maize genome) and at least $45 \%$ of the human genome according to the most common data [1-3] and even up to $66 \%$ according to the analysis by de Koning et al. [4]. TEs are diverse, and two main classes are identified on the base of their mechanism of displacement. Class-I elements, also called retroelements or retrotransposons, use a reverse transcriptase enzyme to copy an RNA transcript into the host DNA, whereas class-II elements, or DNA transposons, mainly move through a "cut and paste" mechanism involving the excision and reinsertion of the DNA sequence of the element [1-3]. Besides, some other mechanisms of transposition exist that, to the best of our knowledge, are not involved in the mobility of human TEs $[1-3,5]$. Both the classes are further subdivided into super-families and then into families on the basis of the transposition mechanism, sequence similarities and/or structural relationships [5]. In addition, a large number of non-autonomous TEs are unable to remove and insert themselves elsewhere in the genome and are dependent of the enzyme(s) encoded by a helper element, which is an autonomous TE. Nevertheless, such non-autonomous TEs have greatly invaded genomes, especially short interspersed nuclear elements (SINEs) that are highly present in mammalian genomes [4].

Class-I elements present in the human genome are divided into Long Terminal Repeats (LTR) and non-LTR elements, the latter being largely predominant (Fig. 1) and account for $76 \%$ of human TEs and at least $33.6 \%$ of the whole human genome [6]. The long interspersed element (LINE)-1 accounts alone for $38 \%$ of the human TEs and $16.9 \%$ of the entire genome (Fig. 1; [6]), followed by the non-autonomous SINE elements, particularly Alu repeats, which account for $24 \%$ of TEs and $10.6 \%$ of the entire genome $[4,6]$. Other SINEs found in humans are MIR and MIR3 elements [4, 6]. The main LTR-elements in the human genome are endogenous retroviruses (HERVs, including HERV-I, HERV-K, HERV-L [6]) that resemble retroviruses in both their structure and mobility mechanism, but lack a functional envelope gene that relegates them to an intracellular existence [3, 7].

Class-II elements, or DNA transposons, are present in small amounts in the human genome, accounting for only $6 \%$ of TEs and $2.8 \%$ of the entire genome (Fig. 1). They mainly belong to the TC-1/mariner superfamily (i.e.mariner, MER2-Tigger, Tc2), hATsuperfamily (i.e. MER1-Charlie, Zaphod), and some PiggyBac-like elements [6]. 


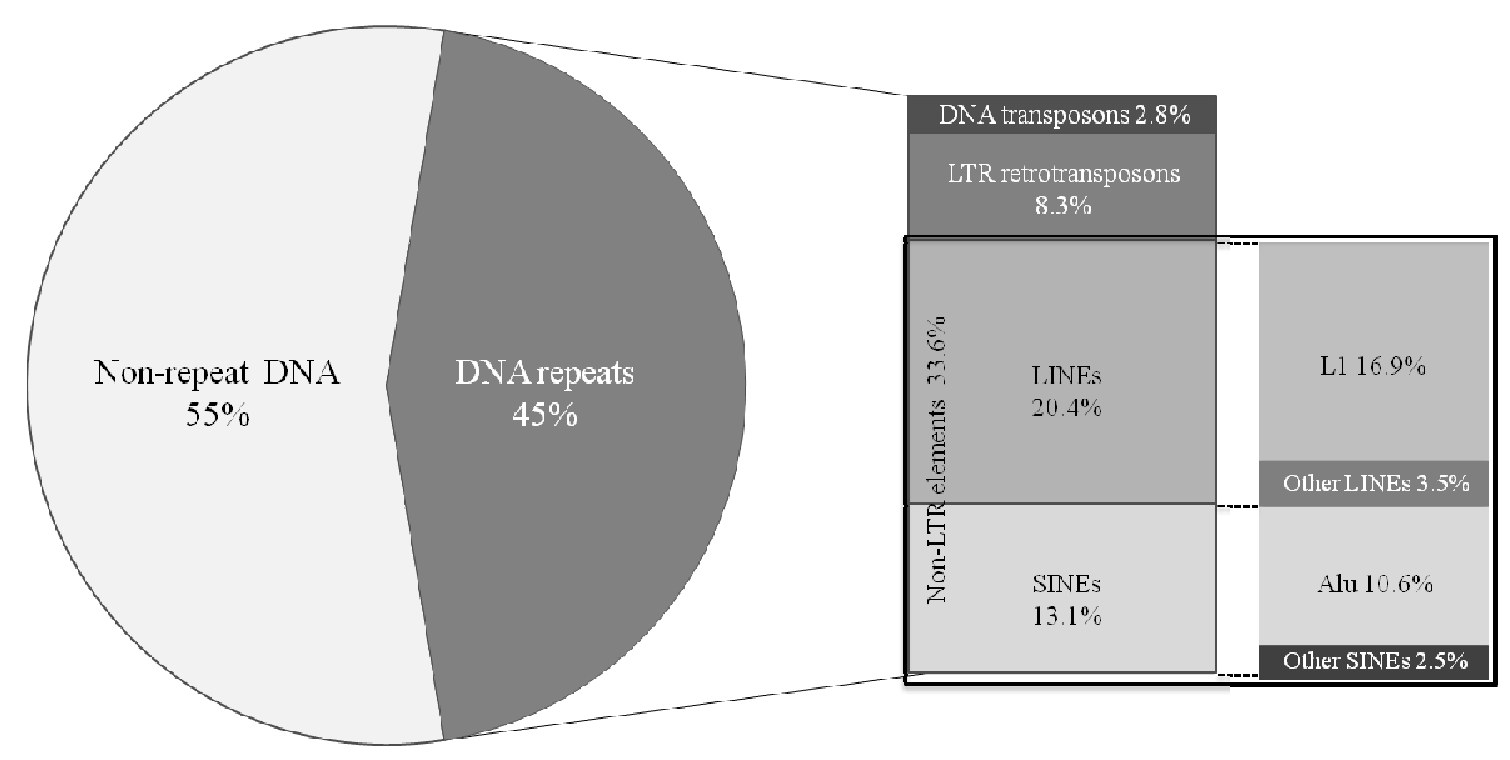

Fig. (1).Proportions of transposable elements in the human genome. The percentage of each class or sub-class of transposable element is given with respect to the whole genome. Data according to [6].

Long been considered as junk DNA or parasite DNA, TEs are now accepted as an evolutionary force that contributes to the genetic diversity of organisms [1-3, 8-10]. Indeed, TE activity is a source of genetic innovation through TE exaptation or domestication, i.e.the recruitment of TE on behalf of the genome to become a new gene [3, 11-12]. The transposition activity may also contribute to the genetic diversity of organisms by: i) acting as gene regulatory elements by providing their own promoters, ii) introducing alternative splicing, or iii) by altering the state of chromatin (reviewed in [3, 11-13]). TEs can also trigger chromosome rearrangements through ectopic recombination between repeated copies of a TE and cause mutations, resulting in several diseases, e.g. cancer, neurological diseases, blood diseases, etc [7, 13-19]. TEs can also regulate gene expression in several different ways, and numerous examples of such gene expression changes by TEs are found in all living organisms [1, 9, 12, 20]. Following are some examples of cancer and other human diseases for which TE-related mechanisms of ontology have been described.

\section{DELETION, DUPLICATION AND CHROMOSOME REARRANGEMENT}

TE-mediated genome rearrangements are known in all living organisms and are at the origin of TE discovery by Barbara McClintock [21]. The large fraction of LINE-1 and Alu repeats 
(i.e. about $17 \%$ and $11 \%$ of the human genome, respectively) favours ectopic recombination, which causes gene deletions, duplications and chromosome translocations or inversions [1]. Indeed, LINE-1 and Alu elements are often observed in the vicinity or even within the breakage points of chromosomal rearrangement [19] and their importance in inversion events and other rearrangement was highlighted by the comparison of human and chimpanzee genomes [22-24]. Furthermore, in a whole genome study of 17 human genomes, Kidd et al. showed that LINE-1retrotranspons account for $19 \%$ of the 2081 breakpoints junction analysed [25].

\section{- Alu recombination and cancer}

Numerous deletion events have been reported at the BRCAl locus and, in a lesser extent, for the BRCA2 gene related to the unusually high density of Alu repeats [26-28] (Table 1). Homologous recombination between Alu elements results sometimes in gene duplication as reported for the BRCA1 gene [27, 29], the MLL-1 gene involved in acute myeloid leukemia [30], and the $M Y B$ proto-oncogene the duplication of which leads to T-cell acute lymphoblastic leukemia [31]. The recombination between Alu repeats is also involved in the generation of the Philadelphia chromosome (i.e. translocation between chromosomes $9 \mathrm{q} 34$ and 22q11) leading to $B C R / A B L$ gene fusions in chronic myeloid leukemia [32]. Another example is the translocation between chromosomes 5q23-31 and 18q12, which is caused by recombination between Alu elements in Ewing sarcoma [33].

\section{- Alu-mediated deletion causing human diseases}

Other than cancer, other diseases may be due to Alu-mediated rearrangements (Table 1). Fabry disease, an X-linked recessive disorder of glycosphingolipid catabolism, results from the deficient activity of the lysosomal hydrolase $\alpha$-galactosidase A, encoded by an Alu-rich gene (12 Alu elements for a $12 \mathrm{~kb}$ gene) [34]. Among the gene rearrangements at the origin of the disease, only one deletion was initially described as due to Alu-Alu recombination, and 10 other Alu-Alu rearangements were identified [34]. More recently, among 50 new mutations at the origin of Fabry disease, one important $3.1 \mathrm{~kb}$ deletion including the whole exon 2 was due to Alu-Alu recombination [35]. In the case of Sandhoff disease, a recessive lysosomal storage disease due to a deficient $\beta$-hexosaminidase activity, Neote et al. demonstrated deletion alleles of the $H E X B$ gene in $27 \%$ of the examined dataset [36]. HEXB contains two Alu repeats that are involved in the deletion event, which removes about $16 \mathrm{~kb}$ including the $H E X B$ promoter, exons 1 to 5, and part of intron 5. The deletion also resulted in a reconstituted Alu sequence, the left half of which comes from the 5' Alu sequence and the right half of which from the 3' Alu sequence [36]. Deletions involving Alu repeats account for 
numerous mutations in several other genes, including the apolipoprotein $\mathrm{B}(A P O B)$ gene[37], the LDL receptor $(L D L R)$ gene (reviewed in [38]), the caspase-activated DNase $(C A D)$ gene [39], the cadherin-1 (CDH1) gene [40], the VHLgene of von Hippel-Lindau disease [41-42], and the $\beta$-globin gene cluster, including $\gamma$-, $\delta$ - and $\beta$-globin genes [43-44] (Table 1).

\section{- LINE-1 and DNA transposons are also source of chromosome rearrangements}

The LINE-1 retroelement is also a source of rearrangement, and a systematic analysis of LINE-1 insertion events in the human genome identified a total of 48 mutations related to L1 retrotransposition causing human genetic disease [45].

Even if they are rare in the human genome, class-II elements may also be responsible of chromosomal rearrangements. Rodic et al. recently reported on ten types of hematolymphoid neoplasms [46]. The conclusion of this work is that most translocations showed no propensity to involve genomic repeats, but $47 \%$ of the translocations at the TCF3 locus on chromosome 19 involve a MER20 DNA transposon [46].

One can be sure that increasing knowledge about TEs will lead to the discovery of growing examples of diseases caused by recombination at TE-rich loci.

Table 1. Examples human diseases linked toTE-mediated deletions or chromosomal rearrangements.

\begin{tabular}{|c|c|c|c|c|}
\hline $\begin{array}{l}\text { Type of } \\
\text { TE }\end{array}$ & Gene & Disease or disorder & $\begin{array}{c}\text { Type of } \\
\text { recombination }\end{array}$ & References \\
\hline Alu & BRCAl & Breast/ovarian cancer & $\begin{array}{l}\text { deletion and } \\
\text { duplication }\end{array}$ & {$[26-27,29]$} \\
\hline Alu & $B R C A 2$ & Breast/ovarian cancer & duplication & {$[27-28]$} \\
\hline Alu & $A P O B$ & Hypo beta lipoproteinemia & deletion & [37] \\
\hline Alu & $C A D$ & hepatoma & deletion & [39] \\
\hline Alu & $C D H 1$ & $\begin{array}{l}\text { Hereditary diffuse gastric } \\
\text { cancer }\end{array}$ & deletion & [40] \\
\hline Alu & $a-G A L A$ & Fabry disease & deletion & {$[34-35]$} \\
\hline Alu & $H B B$ & Thalassemia & deletion & {$[43-44]$} \\
\hline Alu & $H E X B$ & Sandhoff disease & deletion & [36] \\
\hline Alu & $L D L R$ & $\begin{array}{l}\text { familial hyper- } \\
\text { cholesterolemia }\end{array}$ & deletion & [38] \\
\hline Alu & $V H L$ & Von Hippel Lindau disease & deletion & {$[41-42]$} \\
\hline
\end{tabular}




\begin{tabular}{|c|c|c|c|c|}
\hline Alu & MLL1 & Acute myeloid leukemia & duplication & [30] \\
\hline Alu & $M Y B$ & $\begin{array}{l}\text { T-cell lymphoblastic } \\
\text { leukemia }\end{array}$ & duplication & [31] \\
\hline Alu & $B C R-A B L$ & Chronic myeloid leukemia & translocation & [32] \\
\hline Alu & $\begin{array}{l}\text { EWSR 1- } \\
\text { ETV }\end{array}$ & Ewing sarcoma & translocation & [33] \\
\hline$M E R 2 O$ & $T C F 3$ & hematolymphoid neoplasm & translocation & [46] \\
\hline
\end{tabular}

\section{CREATING NEW POLYADENYLATION SITES}

Human retroelements, such as LINE-1 and Alu, may introduce intragenic polyadenylation signals creating new mRNA isoforms that lead to an enrichment of the transcriptome repertoire [47-48]. LINE-1 elements include a polyadenylation signal within their own sequence, and AATAAA sequences are commonly created in the A-rich tails of both SINEs and LINEs. Interestingly the analysis of the conservation and divergence of different types of alternative polyadenylation sites across human, mouse, rat and chicken sequences have shown that non-conserved poly(A) sites are associated with TEs to a much greater extent than conserved ones, albeit less frequently used [49]. Globally, $8 \%$ of total polyA sites are derived from TEs [49]. Approximately $1 \%$ of the reported Alu insertions in the 3' UTR of functional genes act as a polyadenylation sites, $99 \%$ of which are found in forward-oriented Alu elements, even though Alu inserts in 3' UTRs in either direction with the same probability [50]. Polyadenylation has also been observed in the LTR sequence of HERV-K and HERV-H LTRs in the breast cancer cell line T47D [51], in the HHLA2 and HHLA3 genes [52], respectively. Besides, the 5'-LTR sequence of HERV-F, which is notably expressed in placental and fetal tissue, may provide an alternative polyadenylation site to a Krüppel-related zinc finger gene, ZNF195 [53].

Several diseases have been linked to the introduction of a new polyadenylation site through LINE-1 or Alu element insertion in human genes (Table 2), such as colon cancer[54], haemophilia A and B [55-56], X-linked dilated cardiomyopathy [57], autoimmune lymphoproliferative syndrome [58], hypo-calciuric hypercalcemia and neonatal severe hyperparathyroidism [59]. Thus, TEs have played a crucial role during evolution in establishing or altering poly-A sites and sometimes generating human diseases. 
Table 2. Examples of TE-mediated insertions presumed to introduce a new polyadenyation site related to human disease.

\begin{tabular}{|l|l|l|c|}
\hline Type of TE & Gene name & Disease or disorder & References \\
\hline Alu & CASR & $\begin{array}{l}\text { Hypocalciuric hypercalcemia and neonatal } \\
\text { severe hyper-parathyroidism }\end{array}$ & {$[59]$} \\
\hline Alu & $F A S$ & $\begin{array}{l}\text { Autoimmune lympho-proliferative } \\
\text { syndrome }\end{array}$ & {$[58]$} \\
\hline Alu & $F 9$ & Hemophilia B & {$[56]$} \\
\hline LINE-1 & APC & Colon cancer & {$[54]$} \\
\hline LINE-1 & DMD & X-linked dilated cardiomyopathy & {$[57]$} \\
\hline LINE-1 & $F 9$ & Hemophilia B & {$[55]$} \\
\hline
\end{tabular}

\section{EXONIZATION AND ALTERNATIVE SPLICING MODIFICATION}

Most of recent human exons resemble and have originated from highly repeated sequences, i.e. TEs [60]. The molecular mechanisms and evolutionary consequences of such "exonization" (creation of new exons), as well as the creation of new introns ("intronization"), have been described previously [61-62]. In about 79\% of cases, creation of a new exon causes a frameshift or creates premature stop codons, resulting in non-functional sequences, which are often alternatively spliced [61-62]. However, exonization events following LINE-1 or Alu insertion may lead to human diseases (Table 3, Fig. 2).

Table 3. Examples of TE-mediated exonization that cause inactivation of human diseaserelated loci.

\begin{tabular}{|l|l|l|c|}
\hline Type of TE & Gene name & \multicolumn{1}{|c|}{ Disease or disorder } & References \\
\hline$A l u$ & $C O L 4 A 3$ & Alport syndrome & {$[64]$} \\
\hline$A l u$ & $G U S B$ & Sly syndrome & {$[65]$} \\
\hline$A l u$ & $O A T$ & ornithine delta-aminotransferase deficiency & {$[63]$} \\
\hline$A l u$ & $U 2 A F 65$ & Loss of hnRNP C binding leading to aberrant & {$[66]$} \\
& & exonization & \\
\hline LINE-1 & $C Y B B$ & Chronic granulomatous disease & {$[71]$} \\
\hline
\end{tabular}




\section{A) Exon skipping}

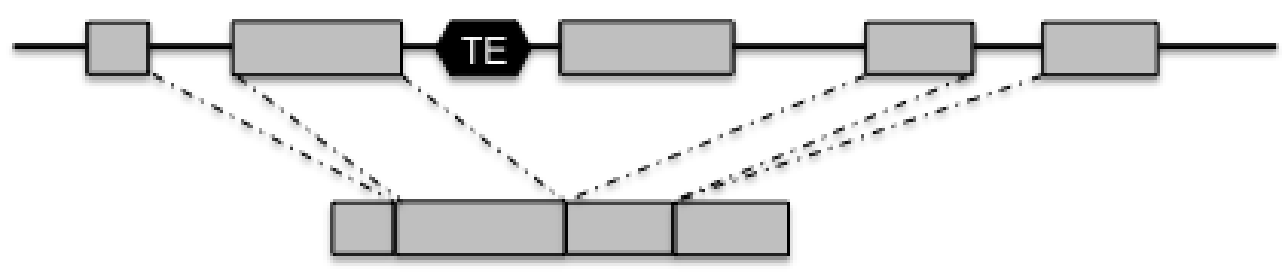

Deleted protein

\section{B) Exonization}

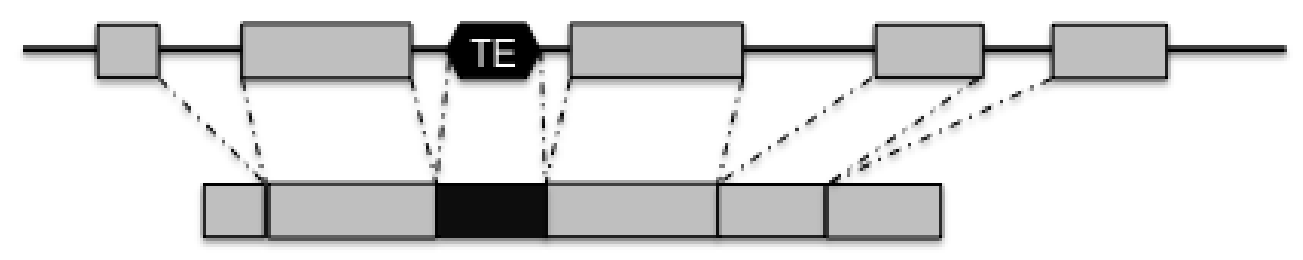

$\rightarrow$ New protein isoform or mRNA degradation

C) Intron retention

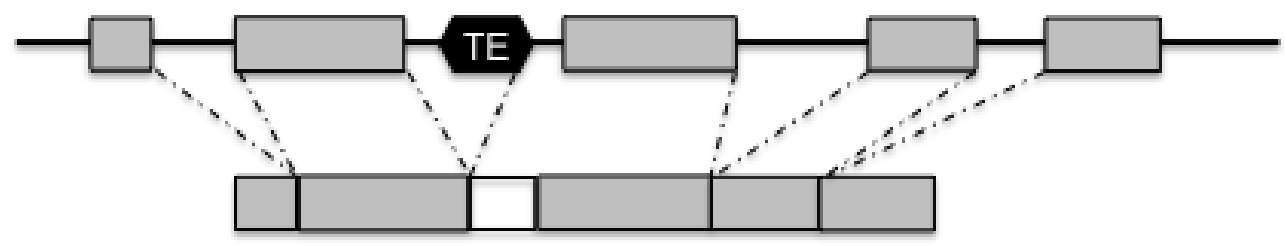

$\rightarrow$ Aberrant protein or mRNA degradation

Fig. (2) Simplified view of the main consequences of $A l u$ insertion on mRNA splicing: A)

Exon skipping; B) exonization; C) intron retention. Grey boxes represent the exons, black line the introns and the black boxes are Alu elements. Dashed lines indicate the splicing events. See text for further explanation.

\section{- Alu-mediated exonization}

For example, a G-to-C mutation in an Alu element present in the intron 3 of the ornithine delta-aminotransferase deficiency (OAT) gene results in the creation of a new donor splice site and potentially to a new exon (Fig. 2B) [63]. This Alu insertion also causes premature termination, which results in OAT deficiency [63]. Two other examples of Alu-mediated exonization have been reported, where mutations in the COL4A3 and GUSB cause Alport [64] and Sly [65] syndromes, respectively. By contrast, a direct competition between the RNA-binding protein hnRNP C and the splicing factor U2AF65 at many genuine and cryptic splice sites has been reported to protect the transcriptome from the exonization of $A l u$ elements [66]. Indeed, hnRNP C, which is abundant in the nucleus and associates with all 
nascent transcripts [67-68], forms hnRNP particles implicated in the regulation of alternative splicing [69-70]. König et al. showed that hnRNP C represses alternative exons by binding next to the splice sites [68]. Besides, the core splicing factor U2AF65 regulates the inclusion of alternative exons on a genomic scale. Zarnack et al. showed that hnRNP C blocks U2AF65 from cryptic 3' splice sites, thereby preventing the aberrant expression of cryptic exons, including Alu elements (Fig.3) [66].
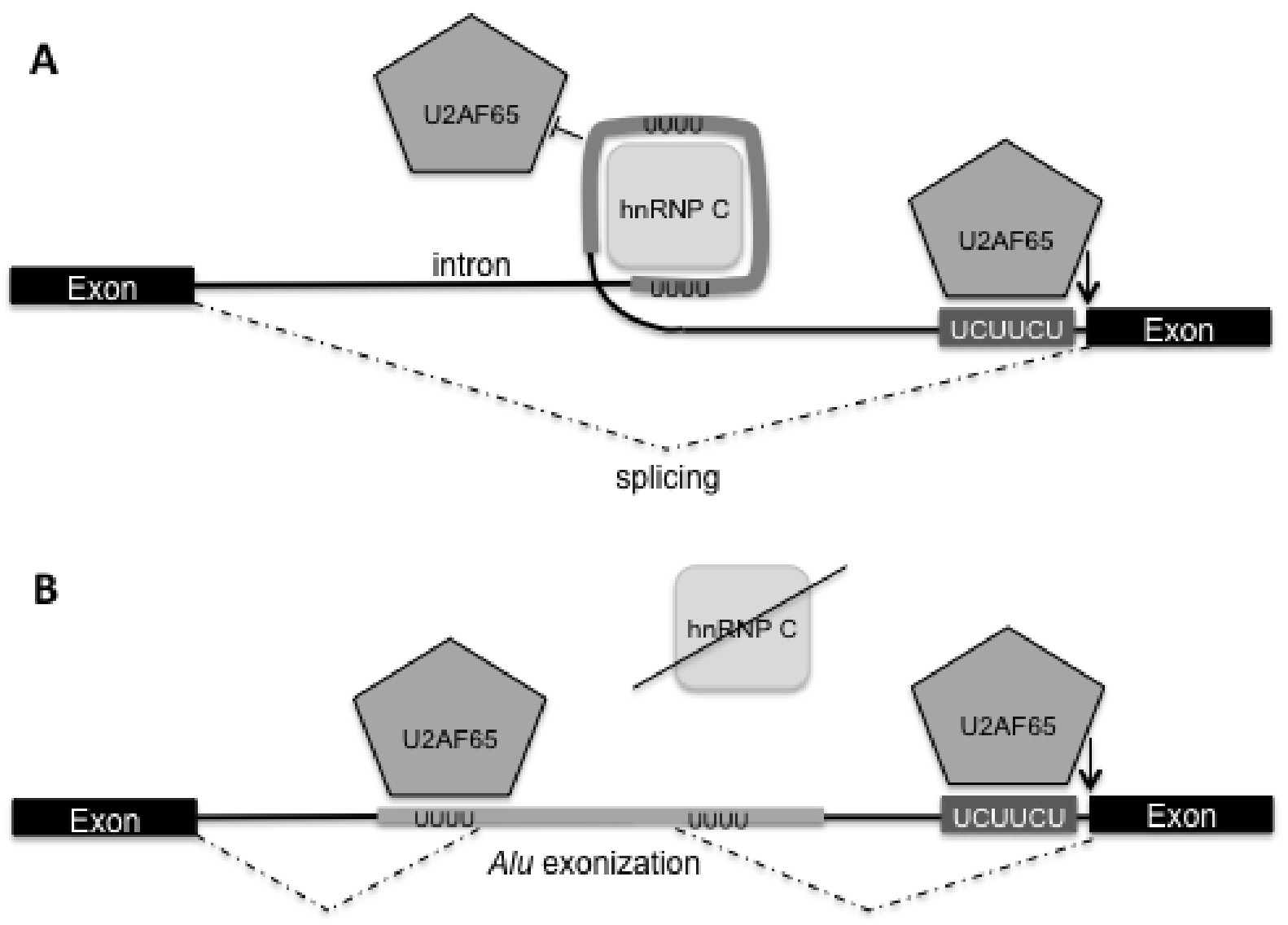

Fig. (3).Protective role of hnRNP C against Alu exonization. A) hnRNP C blocks the binding of the splicing factor U2AF65 on 3' cryptic splice site preventing Alu exonization. B) the absence of hnRNPC or mutation(s) in the polyU tracts prevent hnRNP C binding to Alu element and allow Alu exonization. Figure adapted from [66].

\section{- LINE-1 and ERVs are also source of exons}

The LINE-1 element is also a potential source of exonization as observed for the CYBB gene leading to chronic granulomatous disease [71]. Finally, an obvious example of exonization is provided by the splice acceptor signal and the coding sequence of the C-terminal exon of the human leptin receptor (219.1 isoform), which are derived from the HERV-K homology in a non-autonomous SVA element [72]. 


\section{- Alu- and LINE-1 mediated alternative splicing}

Alternative splicing is often affected by TE insertion (Table 4). For example, insertion of the non-autonomous SINE Alu element into an intron of the human Factor VIII gene results in exon skipping (Fig. 2A) and consequent onset of hemophilia A [73]. In addition, the insertion of a LINE-1 element in the ribosomal S6 kinase 2 (RSK2) gene was reported in a patient with Coffin-Lowry syndrome. This LINE-1 insertion at position -8 of intron 3 leads to a skipping of exon 4 and then to a reading-frame shift and the appearance of a premature stop codon [74]. Another example is the insertion of an Alu sequence into the intron of the NF-1 (neurofibromatosis type I) gene that leads to a deletion and reading frame shift in the downstream exon during splicing, possibly associated with neurofibromatosis [75]. The insertion of an Alu element within the exon 9, or just upstream of the start of exon 9, of the fibroblast growth factor receptor-2 (FGFR2) gene was reported as a cause of Apert syndrome [76]. The latter mutation affects the utilization of the 3' splice site leading to the generation of different, and non-functional, splice forms of FGFR2 transcripts [76].

The dystrophin $(D M D)$ gene is a giant gene (about $2.5 \mathrm{Mb}$ of the $\mathrm{X}$ chromosome with more than 60 exons) where numerous TEs have inserted to create deletions or exon skipping [57, 77-81]. For example the insertion of LINE-1 induces skipping of exon 44, causing Duchenne muscular dystrophy $[79,81]$. Insertion of an Alu-like sequence downstream of intron 11 was observed in individuals with X-linked dilated cardiomyopathy [77]. The insertion induces a rearrangement that activates a cryptic splice site in intron 11 and produces an alternative transcript containing the $A l u$-like sequence and part of the adjacent intron 11, spliced between exons 11 and 12, but not translated due to the presence of numerous stop codons [77]. The LINE-1 element is responsible for a large deletion in the X-linked pyruvate dehydrogenase E1 $(P D H X)$ gene, but the LINE-1 insertion may also lead, at last in one patient, to an aberrantly spliced isoform resulting from the use of two cryptic splice sites [82]. Some other examples are cited in Table 4, but this list is not exhaustive.

\section{- Intron retention: another TE-mediated splicing alteration}

Finally, intron retention (Fig. 2D) may happen when an error occurs in normal splicing leading to retention of a transcript-confirmed intron within a transcript-confirmed exon and thus in the mature mRNA [83]. Such events may be affected by TEs, as demonstrated in the case of LINE-1 insertion in the CYBB gene that causes chronic granulomatous disease [71]. Thus, TE insertions obviously have an impact on gene expression through alteration of splicing, leading to the absence of expression or production of aberrant proteins. 
Table 4. Examples of TE-mediated splicing alterations involved in human diseases.

\begin{tabular}{|c|c|l|c|}
\hline Type of TE & Gene & Disease or disorder & References \\
\hline$A l u$ & $B R C A 2$ & Breast cancer & {$[84]$} \\
\hline$A l u$ & $D M D$ & X-linked dilated cardiomyopathy & {$[77]$} \\
\hline$A l u$ & $F 8$ & Hemophilia A & {$[73]$} \\
\hline$A l u$ & $F A S$ & Autoimmune lymphoproliferative syndrome & {$[58]$} \\
\hline$A l u$ & $F G F R 2$ & Apert syndrome & {$[76]$} \\
\hline$A l u$ & $I D S$ & Hunter syndrome & {$[85]$} \\
\hline$A l u$ & $N F 1$ & Neurofibromatosis type 1 & {$[75]$} \\
\hline$A l u$ & $O P A 1$ & Autosomal dominant opticatrophy & {$[86]$} \\
\hline LINE-1 & $C Y B B$ & Chronic granulomatous disease & {$[71]$} \\
\hline LINE-1 & $D M D$ & Duchenne Muscular Dystrophy & {$[79,81]$} \\
\hline LINE-1 & $F K T N$ & Fukuyama-type congenital muscular dystrophy & {$[87]$} \\
\hline LINE-1 & $R P 2$ & X-linked retinitis pigmentosa & {$[88]$} \\
\hline LINE-1 & $R P S 6 K A 3$ & Coffin-Lowry syndrome & {$[74]$} \\
\hline LINE-1 & $P D H X$ & Pyruvate dehydrogenase complex deficiency & {$[82]$} \\
\hline
\end{tabular}

\section{TE-DERIVED REGULATORY ELEMENTS}

Another way for TE to modify gene expression is to provide cis-regulatory elements at promoter and enhancer regions [89-92]. Numerous cis-regulatory sequences derive from TE domestication or exaptation $[3,11,13]$. Almost $25 \%$ of human promoter regions contain TEderived sequences [93], and numerous transcription factor DNA binding motifs are enriched in various classes of repeats, such as LINE-2, Alu and other SINEs [94-98]. In addition, many of the HERVs present in the human genome have retained functional promoter, enhancer and polyadenylation signals, and these regulatory sequences have the potential to influence the expression of nearby genes.

\section{- ERVs, placenta formation and human embryogenesis}

A crucial role of ERVs in placenta formation has been demonstrated in several mammals [99102]. In humans, the Syncitin-1 and-2 genes are derived from a specific env gene contained within an HERV-W insertion. This Syncytin gene is capable of promoting trophoblast cell fusion in vitro, and likely plays a functional role in placental development [103]. Furthermore, experimental knockout of mouse syncytin results in a lethal placental defect, demonstrating 
the crucial role of ERVs in placental development [104]. The contribution of ERVs to the mammalian genome is also done by providing alternative promoters in their LTRs. LTR exaptation has resulted in a pattern of novel gene expression significantly different from the pattern before LTR insertion or from that of gene orthologs lacking the LTR [90].

In addition, Landry et al. identified a fusion transcript containing the LTR of an HERV-E element linked to the MID1 gene and showed that the retroviral promoter (i.e. LTR) contributes significantly to the level of MIDI transcripts in placenta and embryonic kidney [105]. Furthermore, this study suggests a role for the LTR as a tissue-specific promoter and/or as an enhancer depending on the tissue [105]. Mutations in the MIDl gene, which is known to be transcribed from multiple promoters and to use several 5'untranslated exons [106], affect the development of midline structures and are responsible for the X-linked form of Opitz syndrome [107]. More recently, Teng et al. described enhancers from human embryonic stem cells that are significantly enriched in TE derived sequences, probably due to the generally relaxed repressive epigenetic state and the increased activity of TEs in these cells [91].

\section{- TE-mediated evolution of the galectin gene cluster}

A recent example of the implication of TEs in gene regulation is given by the study of the evolution of the galectin gene cluster on human chromosome 19, where enrichment in a specific LINE-1 element was found in the placental sub-cluster of galectin genes[108]. This is a complex example of promoter evolution since the LINE-1 insertion may be accompanied by Alu insertion, both leading to modified promoters and then to differential expression of the galectin genes[108]. However a direct link with altered galectin expression andpreeclampsia remainsmainly hypothetical.

\section{- Foxal and the a-fetoprotein gene regulation}

Another example of the TE insertion effect in a promoter region was reported by Taube et al., who observed that critical regulatory sites for mouse $\alpha$-fetoprotein overlapping the binding sites of three transcription factors (e.g. Foxa1, p53 and SMAD) are located within a 300 bp region lacking DNA methylation due to the insertion of two TEs in which $\mathrm{CpG}$ sequences are underrepresented [109]. The transcription factor Foxal exploits the lack of methylation of TE sequences to bind and poise chromatin, giving access to secondary transcription factors such as p53 and SMAD, finally leading to $\alpha$-fetoprotein gene expression [109]. However, the methylation status of TEs is variable, depending on the abundance of $\mathrm{CpG}$ islands in the element and on the structure and age of the insertion [110-111]. 


\section{CHROMATIN REGULATION AND TRANSPOSITION}

The structure of constitutive heterochromatin, i.e centromere and telomere, which are essential structures for chromosome function and genome integrity, was contributed in part by TEs. In most eukaryotic species, the centromere consists of long tandem arrays of simple sequence repeats (so-called satellite repeats) surrounded by a peripheral region that is rich in TEs. The satellite regions of human centromeres are generally free of TEs, but pericentromeric regions are composed of long blocks of LINEs and SINEs [112]. In addition, subtelomeric heterochromatin that lies adjacent to the telomeric repeats resembles pericentromeric heterochromatin, and is composed of full-length and fragmented TEs [112]. Moreover, epigenetic imprinting is mostly associated with allele-specific DNA methylation of the $\mathrm{CpG}$ islands, also called germline differentially methylated regions (gDMRs). In several imprinted loci, the gDMRs may have emerged from the insertion of a TE (retrotransposon or ERV) [113]. Examples of such imprinted genes linked to TE insertion include placental transcripts in mammals [114-115] and the FWA gene in Arabidopsis plant model [112, 116117].

In addition, there is a correlation between the activity of TEs and chromatin regulation, mainly in terms of DNA methylation. Thus TE are repressed in methylated DNA regions and, conversely, TE activation is caused by DNA demethylation [118-120]. This assumption is supported by several observations that LINE-1 elements are active in a hypomethylated DNA context. Early embryogenesis is one of these contexts of DNA under-methylation, and LINE1 transposition activity has been demonstrated in murine primordial cells between the E11.5 and E13.5 early embryo stages [121]. Somatic mosaicism was demonstrated in mice due to the transfer of LINE-1 mRNA from the parental tissues (i.e. oocytes or sperm cells) to progeny where reverse transcription ensures further insertions of LINE-1 element's copies into the genome of the developing mouse during the pre-implantation stage [122]. Thus the early embryonic stages of mammal development appear as a favourable field of TE activation and mobility, as at least demonstrated for LINE-1 elements [123]. Therefore TE mobility and especially retroelement insertions, including those leading to cancer and other diseases, may be considered as the cost of phenotypic diversity formation [124]. The relation between LINE-1 activation and the methylation status of DNA has been particularly investigated in the case of cancers. Indeed the frequent hypomethylation of chromatin in tumor cells is regarded as a facilitator of LINE-1 mobility [110, 118-119, 125]. 
Recent whole genome studies revealed preferential LINE-1 insertions in hypomethylated DNA regions of cancer cells of different origins [126-129], while several other studies highlighted the hypomethylation of the LINE-1 element itself in several types of cancers [130-134] (Table 5). LINE-1hypomethylation is accompanied by the shortened relapse-free survival of melanoma patients, and global DNA under-methylation influences the metastatic formation of primary melanomas [135]. The analysis of the transcriptome of chronic lymphocytic leukemia showed that TEs are globally derepressed [128]. However the study by Lee et al., which identified almost two hundred somatic insertions of LINE-1 (94.5\%), Alu (5.0\%) and ERV (0.5\%) in 43 high-coverage whole genome sequencing datasets from five cancer types (i.e. colorectal, glioblastoma, multiple myeloma, ovarian and prostate cancer), shows that all LINE-1 and Alu insertions occurred in epithelial cancer but not in blood and brain cancer [127]. The study by Tubio et al. explored 290 cancer samples from 244 patients among twelve tumor types using a bioinformatic algorithm and identified 2756 somatic LINE-1retrotranspositions [129]. About half of the patients (53\%) had somatic LINE-1 retrotransposition, of which $24 \%$ were 3 'transductions, i.e. concomitant transposition of a unique sequence downstream of the LINE-1 element due to continued transcription beyond the LINE-1 repeat [129]. These authors also highlighted that individual LINE-1 activity fluctuated during tumor evolution and correlated with LINE-1 promoter hypomethylation[129]. In addition somatic LINE-1 insertions tend to disrupt the expression of tumor suppressor genes, which are usually mutated in cancer, suggesting that some TE insertions may provide a selective advantage during tumorigenesis[127]. The role of chromatin structure is further shown through the decreased rate of transcription of the $\beta$ globin $_{\mathrm{L} 1}$ allele, which originated from the insertion of a full length LINE-1 element in intron 2 of the $\beta$-globin gene [136]. Indeed the promoter and enhancer sequences of the $\beta$-globin ${ }_{\mathrm{L} 1}$ allele displayed a hypermethylated profile resulting in a transcriptional down-regulation and thus the $\beta^{+}$-thalassemia phenotype [136].

Table 5. A few examples of LINE-1 hypomethylationrelated to human diseases.

\begin{tabular}{ll}
\hline LINE-1 hypomethylation related disease & References \\
\hline Chronic lymphocytic leukemia & {$[128]$} \\
Hepatocellular carcinoma & {$[131]$} \\
Prostate cancer & {$[130,133-134]$} \\
Colorectal cancer & {$[132]$}
\end{tabular}


Finally, the repression of TEs through RNA interference has been documented and involved essentially endogenous small interfering RNA (endo-siRNA) in somatic cells and PIWIinteracting RNA (piRNA) in the germline (reviewed in $[112,137])$. Both endo-siRNA and piRNA are transcribed from TEs themselves and, despite their sequence diversity, they do not disturb the expression of protein-coding genes [137]. Tumor cells are known to contain significantly lower quantities of micro-RNAs [138], and the question of the endo-siRNA and piRNA expression pattern in cancer cells has to be addressed since it may affect TE activity.

\section{TES AS SCREENING TOOLS FOR CANCER/PATHOLOGIC GENE CANDIDATES}

Animal models and engineered TEs (mainly Sleeping Beauty and PiggyBac, both Class-II DNA transposons) were used to support a causative role of TEs in cancer onset, demonstrating that TE insertion can lead to cancer (reviewed in [14]). Recent input includes the demonstration that Sleeping Beauty transposon system harboring HRAS, c-Myc and shp53 induces sarcomatoid carcinomas in mouse skin [139]. The identification and validation of CUX1 as a tumor suppressor was obtained recently by using mouse transposon-mediated insertional mutagenesis and Drosophila cancer models [140]. Mutagenesis screening allowed the identification of candidate cancer genes (reviewed in [141]), including many established tumor suppressors, oncogenes and genes involved in cell signalling pathways but also new candidates (e.g.diacylglycerol kinase, N(alpha)-acetyltransferase-15,ZNF292, etc.) in various solid tumors [142], non-melanoma skin cancer [143], colorectal cancer [144], glioma [145] and pancreatic adenocarcinoma [146] (Table 6). However, this insertional mutagenesis screening approach is not restricted to cancer and has been recently extended to infectious diseases (e.g.[147-149]). Finally, transposon-based gene trapping is an efficient approach for identifying genes involved in diseases or development ontology as recently used in a zebrafish model to characterize both embryonic and adult recessive mutants with cardiac expression[150]. 
Table 6. Examples of TE-based screening for pathologic genes

\begin{tabular}{|c|c|c|c|c|c|}
\hline Methodology & $\begin{array}{c}\text { Based-on } \\
\text { TE }\end{array}$ & $\begin{array}{c}\text { Model } \\
\text { organism }\end{array}$ & $\begin{array}{l}\text { Target } \\
\text { genes }\end{array}$ & Disease & $\begin{array}{c}\text { Reference } \\
\text { S }\end{array}$ \\
\hline $\begin{array}{c}\text { Target gene } \\
\text { delivery }\end{array}$ & $\begin{array}{c}\text { Sleeping } \\
\text { Beauty }\end{array}$ & mouse & $\begin{array}{l}\text { HRAS, } c- \\
m y c, \text { shp53 }\end{array}$ & $\begin{array}{l}\text { Sarcomatoidca } \\
\text { rcinoma }\end{array}$ & [139] \\
\hline $\begin{array}{l}\text { Insertional } \\
\text { mutagenesis }\end{array}$ & $\begin{array}{l}\text { Sleeping } \\
\text { Beauty }\end{array}$ & mouse & $C U X 1$ & Cancer & {$[140]$} \\
\hline $\begin{array}{l}\text { Insertional } \\
\text { mutagenesis }\end{array}$ & PiggyBac & mouse & diverse & Cancer & [142] \\
\hline $\begin{array}{l}\text { Insertional } \\
\text { mutagenesis }\end{array}$ & $\begin{array}{c}\text { Sleeping } \\
\text { Beauty }\end{array}$ & mouse & $\begin{array}{l}\text { Notchl, } \\
\text { Nsdl, etc }\end{array}$ & $\begin{array}{l}\text { Non- } \\
\text { melanoma } \\
\text { skin cancer }\end{array}$ & {$[143]$} \\
\hline $\begin{array}{l}\text { Insertional } \\
\text { mutagenesis }\end{array}$ & $\begin{array}{l}\text { Sleeping } \\
\text { Beauty }\end{array}$ & mouse & $Z N F 292$ & $\begin{array}{l}\text { Colorectal } \\
\text { cancer }\end{array}$ & [144] \\
\hline $\begin{array}{l}\text { Insertional } \\
\text { mutagenesis }\end{array}$ & $\begin{array}{l}\text { Sleeping } \\
\text { Beauty }\end{array}$ & mouse & $M e t, N f 1$, etc & glioma & [145] \\
\hline $\begin{array}{l}\text { Insertional } \\
\text { mutagenesis }\end{array}$ & $\begin{array}{l}\text { Sleeping } \\
\text { Beauty }\end{array}$ & mouse & $\begin{array}{l}\text { Kras, Mll3, } \\
\text { Ptk } 2, \text { etc }\end{array}$ & $\begin{array}{l}\text { Pancreatic } \\
\text { adenocarcino } \\
\text { ma }\end{array}$ & [146] \\
\hline $\begin{array}{l}\text { Insertional } \\
\text { mutagenesis }\end{array}$ & Himar & $\begin{array}{l}\text { Haemophi } \\
\text { lus } \\
\text { influenzae }\end{array}$ & $\begin{array}{l}i s c R, p g d X \\
\text { pur, etc }\end{array}$ & $\begin{array}{l}\text { Respiratory } \\
\text { infections }\end{array}$ & [147] \\
\hline $\begin{array}{l}\text { Insertional } \\
\text { mutagenesis }\end{array}$ & Himar & Borrelia & diverse & Lyme disease & [148] \\
\hline $\begin{array}{l}\text { Insertional } \\
\text { mutagenesis }\end{array}$ & Himar & $\begin{array}{l}\text { Salmonell } \\
\text { a }\end{array}$ & diverse & $\begin{array}{l}\text { Food-borne } \\
\text { gastroenteritis }\end{array}$ & [149] \\
\hline Gene traping & $\begin{array}{c}R P 2- \\
\text { Gene- } \\
\text { break- } \\
\text { transposon }\end{array}$ & zebrafish & diverse & $\begin{array}{l}\text { Cardiac } \\
\text { organogeny } \\
\text { and pathology }\end{array}$ & {$[150]$} \\
\hline
\end{tabular}




\section{GENE THERAPY OF CANCER AND GENETIC DISORDERS}

Beyond the insertional mutagenesis approach, gene therapy assays have been conducted in animals and human cells in culture using engineered TEs (again mainly Sleeping Beauty and PiggyBac) that avoid some of the drawbacks of classical retroviral vectors (i.e. high mutagenic effect, immune response risk, etc) [151-152]. For example, the anti-angiogenic gene therapy of mice bearing intracranial human glioblastoma was successfully achieved by the transformation of human glioblastoma cells with Sleeping Beauty carrying either the soluble vascular endothelial growth factor receptor gene $(s F l t-1)$ or the angiostatin-endostatin fusion gene (statin-AE), resulting in tumor size reduction and an increased proportion of surviving animals [153]. Otherwise, a gene directed enzyme pro-drug therapy was tested using the PiggyBac vector to treat mouse ovarian cancer and human ovarian adenocarcinoma cells[154-155]. Besides cancers, transposon-based gene therapy of several genetic disorders has been assayed in animal models, including haemophilia A and B, inherited tyrosinemia type I, junctional epidermolysis bullosa, pulmonary hypertension, pulmonary fibrosis, Crigler-Najjar syndrome type I, lung allograft fibrosis, and mucopolysaccharidosis type I and VII (Table 7 and reviewed in [151]). In addition, pathological human cells were tested for ex vivo gene therapy, i.e. the therapeutic gene construct is introduced into a selected cell population removed from the patient and then the treated cells are infused back into the same patient. Using Sleeping Beauty or PiggyBac DNA-transposon based systems, efficient transfection and stable transgene expression were achieved in several types of human stem cells, including cord blood-derived $\mathrm{CD}^{+} 4^{+}$hematopoietic progenitors [156-160], primary $\mathrm{T}$ cells [161-167], and human embryonic stem cells [168-169].

The first clinical application of the Sleeping Beauty system was tested by the group of L.J. Cooper (University of Texas, USA) using autologous T cells genetically modified to redirect specificity to B-lineage malignancies [170]. Several recent improvements have been achieved by the same group. for example eliminating the need to generate patient-specific $\mathrm{T}$ cells and thus rendering the vector suitable for administration in multiple recipients [171-172].

However, much remains to be done before a generalization of transposon-based gene therapy in humans.

Table 7. Examples of successful DNA transposon-based gene delivery in disease models

\begin{tabular}{lllll}
\hline $\begin{array}{l}\text { DNA- } \\
\text { transposon used }\end{array}$ & Disease & Delivered gene(s) & $\begin{array}{l}\text { Model } \\
\text { organism } \\
\text { or cell type }\end{array}$ & References \\
\hline Sleeping Beauty & Hemophilia A & $\begin{array}{l}\text { Human clotting factor } \\
\text { VIII }\end{array}$ & Mouse & {$[173-175]$} \\
& & & &
\end{tabular}




\begin{tabular}{|c|c|c|c|c|}
\hline Sleeping Beauty & Hemophilia B & $\begin{array}{l}\text { Human clotting factor } \\
\text { IX }\end{array}$ & Mouse & {$[176]$} \\
\hline Sleeping Beauty & $\begin{array}{l}\text { Inherited type I } \\
\text { tyrosinemia }\end{array}$ & $\begin{array}{l}\text { Human } \\
\text { fumarylacetoacetate } \\
\text { hydroxylase }\end{array}$ & Mouse & {$[177]$} \\
\hline Sleeping Beauty & Glioblastoma & $\begin{array}{l}\text { soluble endothelium } \\
\text { growth factor receptor } \\
\text { and angiotensin- } \\
\text { endothelin fusion } \\
\text { protein }\end{array}$ & Mouse & {$[153]$} \\
\hline Sleeping Beauty & $\begin{array}{l}\text { Junctional } \\
\text { epidermolysis } \\
\text { bullosa }\end{array}$ & Human laminin- $\beta 3$ & $\begin{array}{l}\text { Human } \\
\text { patient } \\
\text { derived } \\
\text { cells }\end{array}$ & {$[178]$} \\
\hline Sleeping Beauty & $\begin{array}{l}\text { Pulmonary } \\
\text { hypertension }\end{array}$ & $\begin{array}{l}\text { Endothelial } \\
\text { nitricoxidesynthase }\end{array}$ & rat & {$[179]$} \\
\hline Sleeping Beauty & $\begin{array}{l}\text { Lung allograft } \\
\text { fibrosis }\end{array}$ & $\begin{array}{l}\text { human indoleamine-2- } \\
\text { 3-dioxygenase }\end{array}$ & rat & {$[180]$} \\
\hline Sleeping Beauty & $\begin{array}{l}\text { Mucopolysacch } \\
\text { aridosis, type I } \\
\text { and VII }\end{array}$ & $\begin{array}{l}\text { human } \alpha \text {-L-iduronase } \\
\text { and/or human } \beta \text { - } \\
\text { glucuronidase }\end{array}$ & Mouse & [181-182] \\
\hline Sleeping Beauty & $\begin{array}{l}\text { Crigler-Najjar } \\
\text { syndrome, type } \\
\text { I }\end{array}$ & $\begin{array}{l}\text { Uridine- } \\
\text { diphosphoglucuronate } \\
\text { glucuronosyl } \\
\text { transferase-1A1 }\end{array}$ & rat & {$[183]$} \\
\hline PiggyBac & Ovarian cancer & $\begin{array}{l}\text { suicide gene, } \\
\text { i.e.Herpes simplex } \\
\text { thymidine kinase }\end{array}$ & $\begin{array}{l}\text { Mouse } \\
\text { ovarian } \\
\text { tumor }\end{array}$ & {$[154]$} \\
\hline PiggyBac & Ovarian cancer & $\begin{array}{l}\text { suicide gene, i.e. } \\
\text { Herpes simplex } \\
\text { thymidine kinase }\end{array}$ & $\begin{array}{l}\text { Human } \\
\text { ovarian } \\
\text { adenocarcin } \\
\text { oma cell } \\
\text { line }\end{array}$ & {$[155]$} \\
\hline Sleeping Beauty & $\begin{array}{l}\text { B-lymphoid } \\
\text { malignancies }\end{array}$ & $\begin{array}{l}\text { chimeric antigen } \\
\text { receptor }\end{array}$ & $\begin{array}{l}\text { Mouse } \\
\text { primary } \mathrm{T} \\
\text { cells }\end{array}$ & {$[184]$} \\
\hline Sleeping Beauty & $\begin{array}{l}\text { B-lymphoid } \\
\text { malignancies }\end{array}$ & $\begin{array}{l}\text { chimeric antigen } \\
\text { receptor }\end{array}$ & $\begin{array}{l}\text { Primary } \\
\text { human T } \\
\text { cells / } \\
\text { mouse } \\
\text { tumor }\end{array}$ & {$[185]$} \\
\hline PiggyBac & $\begin{array}{l}\text { Solid tumor } \\
\text { (murine } \\
\text { xenograft) }\end{array}$ & $\begin{array}{l}\text { human epidermal } \\
\text { growth factor- } 2- \\
\text { chimeric antigen } \\
\text { receptor fusion }\end{array}$ & $\begin{array}{l}\text { Human } \\
\text { peripheral } \\
\text { blood } \\
\text { mononuclea } \\
\text { r cells }\end{array}$ & {$[166]$} \\
\hline Sleeping Beauty & $\begin{array}{l}\text { Fanconi } \\
\text { anemia, type C }\end{array}$ & $\begin{array}{l}\text { Fanconi anemiagene } \\
\text { C }\end{array}$ & $\begin{array}{l}\text { Human } \\
\text { lymphoblast } \\
\text { oid cells }\end{array}$ & {$[186]$} \\
\hline Sleeping Beauty & Skin & Human $\beta 1$ and $\alpha 2$ & Pig & {$[187]$} \\
\hline
\end{tabular}




\begin{tabular}{lllll} 
Sleeping Beauty & $\begin{array}{l}\text { inflammation } \\
\text { Osteosarcoma } \\
\text { lung metastases }\end{array}$ & $\begin{array}{l}\text { integrin } \\
\text { chimeric antigen } \\
\text { receptor and } \\
\text { interleukin-11 } \\
\text { receptor } \alpha \\
\text { microRNA-29 }\end{array}$ & $\begin{array}{l}\text { T cells / } \\
\text { mouse } \\
\text { tissue }\end{array}$ & [161] \\
Sleeping Beauty & $\begin{array}{l}\text { Mulmonary } \\
\text { fibrosis }\end{array}$ & $\begin{array}{l}\text { Moung lung } \\
\text { tissue }\end{array}$ & {$[188]$} \\
\hline
\end{tabular}

\section{CONCLUSION}

The role of TEs in genome plasticity and evolution is now accepted [1-3, 8-10] but, by the same mechanisms, TEs are also responsible for the molecular etiology of several diseases as presented above $[7,14,16]$. In addition, TEs may become activated by the process of cell malignant transformation that promotes increased rates of mutation and recombination in the genome of transformed cells [14]. It seems important to disseminate knowledge of TEs to a wide audience of scientists and physicians, keeping in mind that genomes are continuously evolving due to TEs and that new genetic defects will continue to appear, even at a slow rate in the case of Humans. Some examples have been cited above, but the list presented here of human diseases related to TE insertion events is far from exhaustive. Increasing our knowledge of TEs through extensive genomic approaches may lead to new potential diagnostic markers of diseases and prenatal markers of genetic disorders. Another interesting aspect of TEs is their potential use as biotechnology tools for gene therapy, although further progress is required, such as the control of insertion point. Site-specific insertion has been observed with yeast retrotransposon Ty1 [189-190] and with the bacterial transposon Tn7. $\operatorname{Tn} 7$ specifically inserts at the chromosomal attachment site att $\operatorname{Tn} 7$ or in non-att $\operatorname{Tn} 7$ sites in conjugal plasmids depending on the transposition proteins expressed [191-192]. Indeed, four Tn7 proteins act as target selector; when TnsD is the target selector, Tn7 inserts at high frequency into the E. coli attTn7 site, directly downstream of the essential glmS gene, whose expression is preserved [191, 193]. This exceptional property of $\operatorname{Tn} 7$ transposon leads to the engineering of mini- $\operatorname{Tn} 7$ transposons used as a tool for a single-copy tagging of various bacteria in a site-specific manner at a unique and neutral site without any deleterious effects (reviewed in [194]). Interestingly the site-specific insertion of Tn7 was also found in the human genome but not in yeast [195].

ACKNOWLEDGEMENT: The author is grateful to the reviewers for their valuable inputs and to Mrs Chitra Madomercandy for revising the English text. 
CONFLICT OF INTEREST: The author declares that there are no conflicts of interest.

\section{REFERENCES}

1. Chénais, B.; Caruso, A.; Hiard, S.; Casse, N., The impact of transposable elements on eukaryotic genomes: from genome size increase to genetic adaptation to stressful environments. Gene 2012,509 (1), 7-15.

2. Pritham, E. J., Transposable elements and factors influencing their success in eukaryotes. J. Hered. 2009,100 (5), 648-55.

3. Levin, H. L., Moran, J. V., Dynamic interactions between transposable elements and their hosts. Nat. Rev. Genet. 2011,12 (9), 615-27.

4. de Koning, A. P.; Gu, W.; Castoe, T. A.; Batzer, M. A.; Pollock, D. D., Repetitive elements may comprise over two-thirds of the human genome. PLoS Genet. 2011,7 (12), e1002384.

5. Wicker, T.; Sabot, F.; Hua-Van, A.; Bennetzen, J. L.; Capy, P.; Chalhoub, B.; Flavell, A.; Leroy, P.; Morgante, M.; Panaud, O.; Paux, E.; SanMiguel, P.; Schulman, A. H., A unified classification system for eukaryotic transposable elements. Nat. Rev. Genet. 2007,8 (12), 973-82.

6. $\quad$ Lander, E. S.; Linton, L. M.; Birren, B.; Nusbaum, C.; Zody, M. C.; Baldwin, J.; Devon, K.; Dewar, K.; Doyle, M.; FitzHugh, W.; Funke, R.; Gage, D.; Harris, K.; Heaford, A.; Howland, J.; Kann, L.; Lehoczky, J.; LeVine, R.; McEwan, P.; McKernan, K.; Meldrim, J.; Mesirov, J. P.; Miranda, C.; Morris, W.; Naylor, J.; Raymond, C.; Rosetti, M.; Santos, R.; Sheridan, A.; Sougnez, C.; Stange-Thomann, N.; Stojanovic, N.; Subramanian, A.; Wyman, D.; Rogers, J.; Sulston, J.; Ainscough, R.; Beck, S.; Bentley, D.; Burton, J.; Clee, C.; Carter, N.; Coulson, A.; Deadman, R.; Deloukas, P.; Dunham, A.; Dunham, I.; Durbin, R.; French, L.; Grafham, D.; Gregory, S.; Hubbard, T.; Humphray, S.; Hunt, A.; Jones, M.; Lloyd, C.; McMurray, A.; Matthews, L.; Mercer, S.; Milne, S.; Mullikin, J. C.; Mungall, A.; Plumb, R.; Ross, M.; Shownkeen, R.; Sims, S.; Waterston, R. H.; Wilson, R. K.; Hillier, L. W.; McPherson, J. D.; Marra, M. A.; Mardis, E. R.; Fulton, L. A.; Chinwalla, A. T.; Pepin, K. H.; Gish, W. R.; Chissoe, S. L.; Wendl, M. C.; Delehaunty, K. D.; Miner, T. L.; Delehaunty, A.; Kramer, J. B.; Cook, L. L.; Fulton, R. S.; Johnson, D. L.; Minx, P. J.; Clifton, S. W.; Hawkins, T.; Branscomb, E.; Predki, P.; Richardson, P.; Wenning, S.; Slezak, T.; Doggett, N.; Cheng, J. F.; Olsen, A.; Lucas, S.; Elkin, C.; Uberbacher, E.; Frazier, M.; Gibbs, R. A.; Muzny, D. M.; Scherer, S. E.; Bouck, J. B.; Sodergren, E. J.; Worley, K. C.; Rives, C. M.; Gorrell, J. H.; Metzker, M. L.; Naylor, S. L.; Kucherlapati, R. S.; Nelson, D. L.; Weinstock, G. M.; Sakaki, Y.; Fujiyama, A.; Hattori, M.; Yada, T.; Toyoda, A.; Itoh, T.; Kawagoe, C.; Watanabe, H.; Totoki, Y.; Taylor, T.; Weissenbach, J.; Heilig, R.; Saurin, W.; Artiguenave, F.; Brottier, P.; Bruls, T.; Pelletier, E.; Robert, C.; Wincker, P.; Smith, D. R.; Doucette-Stamm, L.; Rubenfield, M.; Weinstock, K.; Lee, H. M.; Dubois, J.; Rosenthal, A.; Platzer, M.; Nyakatura, G.; Taudien, S.; Rump, A.; Yang, H.; Yu, J.; Wang, J.; Huang, G.; Gu, J.; Hood, L.; Rowen, L.; Madan, A.; Qin, S.; Davis, R. W.; Federspiel, N. A.; Abola, A. P.; Proctor, M. J.; Myers, R. M.; Schmutz, J.; Dickson, M.; Grimwood, J.; Cox, D. R.; Olson, M. V.; Kaul, R.; Shimizu, N.; Kawasaki, K.; Minoshima, S.; Evans, G. A.; Athanasiou, M.; Schultz, R.; Roe, B. A.; Chen, F.; Pan, H.; Ramser, J.; Lehrach, H.; Reinhardt, R.; McCombie, W. R.; de la Bastide, M.; Dedhia, N.; Blocker, H.; Hornischer, K.; Nordsiek, G.; Agarwala, R.; Aravind, L.; 
Bailey, J. A.; Bateman, A.; Batzoglou, S.; Birney, E.; Bork, P.; Brown, D. G.; Burge, C. B.; Cerutti, L.; Chen, H. C.; Church, D.; Clamp, M.; Copley, R. R.; Doerks, T.; Eddy, S. R.; Eichler, E. E.; Furey, T. S.; Galagan, J.; Gilbert, J. G.; Harmon, C.; Hayashizaki, Y.; Haussler, D.; Hermjakob, H.; Hokamp, K.; Jang, W.; Johnson, L. S.; Jones, T. A.; Kasif, S.; Kaspryzk, A.; Kennedy, S.; Kent, W. J.; Kitts, P.; Koonin, E. V.; Korf, I.; Kulp, D.; Lancet, D.; Lowe, T. M.; McLysaght, A.; Mikkelsen, T.; Moran, J. V.; Mulder, N.; Pollara, V. J.; Ponting, C. P.; Schuler, G.; Schultz, J.; Slater, G.; Smit, A. F.; Stupka, E.; Szustakowski, J.; Thierry-Mieg, D.; Thierry-Mieg, J.; Wagner, L.; Wallis, J.; Wheeler, R.; Williams, A.; Wolf, Y. I.; Wolfe, K. H.; Yang, S. P.; Yeh, R. F.; Collins, F.; Guyer, M. S.; Peterson, J.; Felsenfeld, A.; Wetterstrand, K. A.; Patrinos, A.; Morgan, M. J.; de Jong, P.; Catanese, J. J.; Osoegawa, K.; Shizuya, H.; Choi, S.; Chen, Y. J., Initial sequencing and analysis of the human genome. Nature 2001,409 (6822), 860-921.

7. Beck, C. R.; Garcia-Perez, J. L.; Badge, R. M.; Moran, J. V., LINE-1 elements in structural variation and disease. Annu. Rev. Genomics Hum. Genet. 2011,12, 187-215.

8. Biemont, C.; Vieira, C., Genetics: junk DNA as an evolutionary force. Nature 2006,443 (7111), 521-4.

9. Cordaux, R.; Batzer, M. A., The impact of retrotransposons on human genome evolution. Nat. Rev. Genet. 2009,10 (10), 691-703.

10. Feschotte, C.; Pritham, E. J., DNA transposons and the evolution of eukaryotic genomes. Annu. Rev. Genet. 2007,41, 331-68.

11. Feschotte, C., Transposable elements and the evolution of regulatory networks. Nat. Rev. Genet. 2008,9 (5), 397-405.

12. Sinzelle, L.; Izsvak, Z.; Ivics, Z., Molecular domestication of transposable elements: from detrimental parasites to useful host genes. Cell. Mol. Life Sci. 2009,66 (6), 107393.

13. Bourque, G., Transposable elements in gene regulation and in the evolution of vertebrate genomes. Curr. Opin. Genet. Dev. 2009,19 (6), 607-12.

14. Chénais, B., Transposable elements and human cancer: a causal relationship? Biochim. Biophys. Acta 2013,1835 (1), 28-35.

15. Belancio, V. P.; Roy-Engel, A. M.; Deininger, P. L., All y'all need to know 'bout retroelements in cancer. Semin. Cancer Biol. 2010,20 (4), 200-10.

16. Konkel, M. K.; Batzer, M. A., A mobile threat to genome stability: The impact of nonLTR retrotransposons upon the human genome. Semin. Cancer Biol. 2010,20 (4), 21121.

17. Kozeretska, I. A.; Demydov, S. V.; Ostapchenko, L. I., Mobile genetic elements and cancer. From mutations to gene therapy. Exp. Oncol. 2011,33 (4), 198-205.

18. Lerat, E.; Semon, M., Influence of the transposable element neighborhood on human gene expression in normal and tumor tissues. Gene 2007,396 (2), 303-11.

19. Zhao, H.; Bourque, G., Recovering genome rearrangements in the mammalian phylogeny. Genome Res. 2009,19 (5), 934-42.

20. Feschotte, C.; Keswani, U.; Ranganathan, N.; Guibotsy, M. L.; Levine, D., Exploring repetitive DNA landscapes using REPCLASS, a tool that automates the classification of transposable elements in eukaryotic genomes. Genome Biol. Evol. 2009,1, 205-20.

21. McClintock, B., The discovery and characterization of transposable elements: the collected papers of B. McClintock. Garland: New York, 1987.

22. Han, K.; Lee, J.; Meyer, T. J.; Remedios, P.; Goodwin, L.; Batzer, M. A., L1 recombination-associated deletions generate human genomic variation. Proc. Natl. Acad. Sci. U. S. A.2008,105 (49), 19366-71. 
23. Kim, P. M.; Lam, H. Y.; Urban, A. E.; Korbel, J. O.; Affourtit, J.; Grubert, F.; Chen, X.; Weissman, S.; Snyder, M.; Gerstein, M. B., Analysis of copy number variants and segmental duplications in the human genome: Evidence for a change in the process of formation in recent evolutionary history. Genome Res.2008,18 (12), 1865-74.

24. Lee, J.; Han, K.; Meyer, T. J.; Kim, H. S.; Batzer, M. A., Chromosomal inversions between human and chimpanzee lineages caused by retrotransposons. PloS One 2008,3 (12), e4047.

25. Kidd, J. M.; Graves, T.; Newman, T. L.; Fulton, R.; Hayden, H. S.; Malig, M.; Kallicki, J.; Kaul, R.; Wilson, R. K.; Eichler, E. E., A human genome structural variation sequencing resource reveals insights into mutational mechanisms. Cell 2010,143 (5), 837-47.

26. Armaou, S.; Konstantopoulou, I.; Anagnostopoulos, T.; Razis, E.; Boukovinas, I.; Xenidis, N.; Fountzilas, G.; Yannoukakos, D., Novel genomic rearrangements in the BRCA1 gene detected in Greek breast/ovarian cancer patients. Eur. J. Cancer 2007,43 (2), 443-53.

27. Mazoyer, S., Genomic rearrangements in the BRCA1 and BRCA2 genes. Hum. Mutat. 2005,25 (5), 415-22.

28. Tournier, I.; Paillerets, B. B.; Sobol, H.; Stoppa-Lyonnet, D.; Lidereau, R.; Barrois, M.; Mazoyer, S.; Coulet, F.; Hardouin, A.; Chompret, A.; Lortholary, A.; Chappuis, P.; Bourdon, V.; Bonadona, V.; Maugard, C.; Gilbert, B.; Nogues, C.; Frebourg, T.; Tosi, M., Significant contribution of germline BRCA2 rearrangements in male breast cancer families. Cancer Res. 2004,64 (22), 8143-7.

29. Yap, K. P.; Ang, P.; Lim, I. H.; Ho, G. H.; Lee, A. S., Detection of a novel Alumediated BRCA1 exon 13 duplication in Chinese breast cancer patients and implications for genetic testing. Clin. Genet. 2006,70 (1), 80-2.

30. Strout, M. P.; Marcucci, G.; Bloomfield, C. D.; Caligiuri, M. A., The partial tandem duplication of ALL1 (MLL) is consistently generated by Alu-mediated homologous recombination in acute myeloid leukemia. Proc. Natl. Acad. Sci. U. S. A. 1998,95 (5), 2390-5.

31. O'Neil, J.; Tchinda, J.; Gutierrez, A.; Moreau, L.; Maser, R. S.; Wong, K. K.; Li, W.; McKenna, K.; Liu, X. S.; Feng, B.; Neuberg, D.; Silverman, L.; DeAngelo, D. J.; Kutok, J. L.; Rothstein, R.; DePinho, R. A.; Chin, L.; Lee, C.; Look, A. T., Alu elements mediate MYB gene tandem duplication in human T-ALL. J. Exp. Med. 2007,204 (13), 3059-66.

32. Jeffs, A. R.; Benjes, S. M.; Smith, T. L.; Sowerby, S. J.; Morris, C. M., The BCR gene recombines preferentially with Alu elements in complex BCR-ABL translocations of chronic myeloid leukaemia. Hum. Mol. Genet. 1998,7 (5), 767-76.

33. Onno, M.; Nakamura, T.; Hillova, J.; Hill, M., Rearrangement of the human tre oncogene by homologous recombination between Alu repeats of nucleotide sequences from two different chromosomes. Oncogene 1992,7 (12), 2519-23.

34. Kornreich, R.; Bishop, D. F.; Desnick, R. J., Alpha-galactosidase A gene rearrangements causing Fabry disease. Identification of short direct repeats at breakpoints in an Alu-rich gene. J. Biol. Chem. 1990,265 (16), 9319-26.

35. Shabbeer, J.; Yasuda, M.; Benson, S. D.; Desnick, R. J., Fabry disease: identification of 50 novel alpha-galactosidase A mutations causing the classic phenotype and threedimensional structural analysis of 29 missense mutations. Hum. Genomics 2006,2 (5), 297-309.

36. Neote, K.; McInnes, B.; Mahuran, D. J.; Gravel, R. A., Structure and distribution of an Alu-type deletion mutation in Sandhoff disease. J. Clin. Invest. 1990,86 (5), 1524-31. 
37. Huang, L. S.; Ripps, M. E.; Korman, S. H.; Deckelbaum, R. J.; Breslow, J. L., Hypobetalipoproteinemia due to an apolipoprotein B gene exon 21 deletion derived by Alu-Alu recombination. J. Biol. Chem. 1989,264 (19), 11394-400.

38. Hobbs, H. H.; Brown, M. S.; Goldstein, J. L., Molecular genetics of the LDL receptor gene in familial hypercholesterolemia. Hum. Mutat. 1992,1 (6), 445-66.

39. Hsieh, S. Y.; Chen, W. Y.; Yeh, T. S.; Sheen, I. S.; Huang, S. F., High-frequency Alumediated genomic recombination/deletion within the caspase-activated DNase gene in human hepatoma. Oncogene 2005,24 (43), 6584-9.

40. Oliveira, C.; Senz, J.; Kaurah, P.; Pinheiro, H.; Sanges, R.; Haegert, A.; Corso, G.; Schouten, J.; Fitzgerald, R.; Vogelsang, H.; Keller, G.; Dwerryhouse, S.; Grimmer, D.; Chin, S. F.; Yang, H. K.; Jackson, C. E.; Seruca, R.; Roviello, F.; Stupka, E.; Caldas, C.; Huntsman, D., Germline CDH1 deletions in hereditary diffuse gastric cancer families. Hum. Mol. Genet. 2009,18 (9), 1545-55.

41. Casarin, A.; Martella, M.; Polli, R.; Leonardi, E.; Anesi, L.; Murgia, A., Molecular characterization of large deletions in the von Hippel-Lindau (VHL) gene by quantitative real-time PCR: the hypothesis of an alu-mediated mechanism underlying VHL gene rearrangements. Mol. Diagn. Ther. 2006,10 (4), 243-9.

42. Franke, G.; Bausch, B.; Hoffmann, M. M.; Cybulla, M.; Wilhelm, C.; Kohlhase, J.; Scherer, G.; Neumann, H. P., Alu-Alu recombination underlies the vast majority of large VHL germline deletions: Molecular characterization and genotype-phenotype correlations in VHL patients. Hum. Mutat. 2009,30 (5), 776-86.

43. Jagadeeswaran, P.; Tuan, D.; Forget, B. G.; Weissman, S. M., A gene deletion ending at the midpoint of a repetitive DNA sequence in one form of hereditary persistence of fetal haemoglobin. Nature 1982,296 (5856), 469-70.

44. Ottolenghi, S.; Giglioni, B., The deletion in a type of delta 0-beta 0-thalassaemia begins in an inverted AluI repeat. Nature 1982,300 (5894), 770-1.

45. Chen, J. M.; Stenson, P. D.; Cooper, D. N.; Ferec, C., A systematic analysis of LINE-1 endonuclease-dependent retrotranspositional events causing human genetic disease. Hum. Genet. 2005,117 (5), 411-27.

46. Rodic, N.; Zampella, J. G.; Cornish, T. C.; Wheelan, S. J.; Burns, K. H., Translocation junctions in TCF3-PBX1 acute lymphoblastic leukemia/lymphoma cluster near transposable elements. Mobile DNA 2013,4 (1), 22.

47. Perepelitsa-Belancio, V.; Deininger, P., RNA truncation by premature polyadenylation attenuates human mobile element activity. Nat. Genet. 2003,35 (4), 363-6.

48. Roy-Engel, A. M.; El-Sawy, M.; Farooq, L.; Odom, G. L.; Perepelitsa-Belancio, V.; Bruch, H.; Oyeniran, O. O.; Deininger, P. L., Human retroelements may introduce intragenic polyadenylation signals. Cytogenet. Genome Res. 2005,110 (1-4), 365-71.

49. Lee, J. Y.; Ji, Z.; Tian, B., Phylogenetic analysis of mRNA polyadenylation sites reveals a role of transposable elements in evolution of the 3'-end of genes. Nucleic Acids Res. 2008,36 (17), 5581-90.

50. Chen, C.; Ara, T.; Gautheret, D., Using Alu elements as polyadenylation sites: A case of retroposon exaptation. Mol. Biol. Evol.2009,26 (2), 327-34.

51. Baust, C.; Seifarth, W.; Germaier, H.; Hehlmann, R.; Leib-Mosch, C., HERV-K-T47DRelated long terminal repeats mediate polyadenylation of cellular transcripts. Genomics 2000,66 (1), 98-103.

52. Mager, D. L.; Hunter, D. G.; Schertzer, M.; Freeman, J. D., Endogenous retroviruses provide the primary polyadenylation signal for two new human genes (HHLA2 and HHLA3). Genomics 1999,59 (3), 255-63. 
53. Kjellman, C.; Sjogren, H. O.; Salford, L. G.; Widegren, B., HERV-F (XA34) is a fulllength human endogenous retrovirus expressed in placental and fetal tissues. Gene 1999,239 (1), 99-107.

54. Miki, Y.; Nishisho, I.; Horii, A.; Miyoshi, Y.; Utsunomiya, J.; Kinzler, K. W.; Vogelstein, B.; Nakamura, Y., Disruption of the APC gene by a retrotransposal insertion of L1 sequence in a colon cancer. Cancer Res. 1992,52 (3), 643-5.

55. Mukherjee, S.; Mukhopadhyay, A.; Banerjee, D.; Chandak, G. R.; Ray, K., Molecular pathology of haemophilia B: identification of five novel mutations including a LINE 1 insertion in Indian patients. Haemophilia 2004,10 (3), 259-63.

56. Vidaud, D.; Vidaud, M.; Bahnak, B. R.; Siguret, V.; Gispert Sanchez, S.; Laurian, Y.; Meyer, D.; Goossens, M.; Lavergne, J. M., Haemophilia B due to a de novo insertion of a human-specific Alu subfamily member within the coding region of the factor IX gene. Eur. J. Hum. Genet.1993,1 (1), 30-6.

57. Yoshida, K.; Nakamura, A.; Yazaki, M.; Ikeda, S.; Takeda, S., Insertional mutation by transposable element, L1, in the DMD gene results in X-linked dilated cardiomyopathy. Hum. Mol. Genet. 1998,7 (7), 1129-32.

58. Tighe, P. J.; Stevens, S. E.; Dempsey, S.; Le Deist, F.; Rieux-Laucat, F.; Edgar, J. D., Inactivation of the Fas gene by Alu insertion: retrotransposition in an intron causing splicing variation and autoimmune lymphoproliferative syndrome. Genes Immun.2002,3 Suppl 1, S66-70.

59. Janicic, N.; Pausova, Z.; Cole, D. E.; Hendy, G. N., Insertion of an Alu sequence in the $\mathrm{Ca}(2+)$-sensing receptor gene in familial hypocalciuric hypercalcemia and neonatal severe hyperparathyroidism. Am. J. Hum. Genet.1995,56 (4), 880-6.

60. Zhang, X. H.; Chasin, L. A., Comparison of multiple vertebrate genomes reveals the birth and evolution of human exons. Proc. Natl. Acad. Sci. U. S. A. 2006,103 (36), 13427-32.

61. Sela, N.; Mersch, B.; Gal-Mark, N.; Lev-Maor, G.; Hotz-Wagenblatt, A.; Ast, G., Comparative analysis of transposed element insertion within human and mouse genomes reveals Alu's unique role in shaping the human transcriptome. Genome Biol. 2007,8 (6), R127.

62. Sorek, R., The birth of new exons: mechanisms and evolutionary consequences. $R N A$ 2007,13 (10), 1603-8.

63. Mitchell, G. A.; Labuda, D.; Fontaine, G.; Saudubray, J. M.; Bonnefont, J. P.; Lyonnet, S.; Brody, L. C.; Steel, G.; Obie, C.; Valle, D., Splice-mediated insertion of an Alu sequence inactivates ornithine delta-aminotransferase: a role for Alu elements in human mutation. Proc. Natl. Acad. Sci. U. S. A. 1991,88 (3), 815-9.

64. Knebelmann, B.; Forestier, L.; Drouot, L.; Quinones, S.; Chuet, C.; Benessy, F.; Saus, J.; Antignac, C., Splice-mediated insertion of an Alu sequence in the COL4A3 mRNA causing autosomal recessive Alport syndrome. Hum. Mol. Genet.1995,4 (4), 675-9.

65. Vervoort, R.; Gitzelmann, R.; Lissens, W.; Liebaers, I., A mutation (IVS8+0.6kbdelTC) creating a new donor splice site activates a cryptic exon in an Alu-element in intron 8 of the human beta-glucuronidase gene. Hum. Genet.1998,103 (6), 686-93.

66. Zarnack, K.; Konig, J.; Tajnik, M.; Martincorena, I.; Eustermann, S.; Stevant, I.; Reyes, A.; Anders, S.; Luscombe, N. M.; Ule, J., Direct competition between hnRNP C and U2AF65 protects the transcriptome from the exonization of Alu elements. Cell 2013,152 (3), 453-66.

67. Beyer, A. L.; Christensen, M. E.; Walker, B. W.; LeStourgeon, W. M., Identification and characterization of the packaging proteins of core 40S hnRNP particles. Cell 1977,11 (1), 127-38. 
68. Konig, J.; Zarnack, K.; Rot, G.; Curk, T.; Kayikci, M.; Zupan, B.; Turner, D. J.; Luscombe, N. M.; Ule, J., iCLIP reveals the function of hnRNP particles in splicing at individual nucleotide resolution. Nat. Struct. Mol. Biol. 2010,17 (7), 909-15.

69. Choi, Y. D.; Grabowski, P. J.; Sharp, P. A.; Dreyfuss, G., Heterogeneous nuclear ribonucleoproteins: role in RNA splicing. Science 1986,231 (4745), 1534-9.

70. Dreyfuss, G.; Matunis, M. J.; Pinol-Roma, S.; Burd, C. G., hnRNP proteins and the biogenesis of mRNA. Ann. Rev.Biochem.1993,62, 289-321.

71. Meischl, C.; Boer, M.; Ahlin, A.; Roos, D., A new exon created by intronic insertion of a rearranged LINE-1 element as the cause of chronic granulomatous disease. Eur. J.

Hum. Genet.2000,8 (9), 697-703.

72. Damert, A.; Lower, J.; Lower, R., Leptin receptor isoform 219.1: an example of protein evolution by LINE-1-mediated human-specific retrotransposition of a coding SVA element. Mol. Biol. Evol.2004,21 (4), 647-51.

73. Ganguly, A.; Dunbar, T.; Chen, P.; Godmilow, L.; Ganguly, T., Exon skipping caused by an intronic insertion of a young Alu $\mathrm{Yb} 9$ element leads to severe hemophilia A. Hum. Genet.2003,113 (4), 348-52.

74. Martinez-Garay, I.; Ballesta, M. J.; Oltra, S.; Orellana, C.; Palomeque, A.; Molto, M. D.; Prieto, F.; Martinez, F., Intronic L1 insertion and F268S, novel mutations in RPS6KA3 (RSK2) causing Coffin-Lowry syndrome. Clin. Genet. 2003,64 (6), 491-6.

75. Wallace, M. R.; Andersen, L. B.; Saulino, A. M.; Gregory, P. E.; Glover, T. W.; Collins, F. S., A de novo Alu insertion results in neurofibromatosis type 1. Nature 1991,353 (6347), 864-6.

76. Oldridge, M.; Zackai, E. H.; McDonald-McGinn, D. M.; Iseki, S.; Morriss-Kay, G. M.; Twigg, S. R.; Johnson, D.; Wall, S. A.; Jiang, W.; Theda, C.; Jabs, E. W.; Wilkie, A. O., De novo alu-element insertions in FGFR2 identify a distinct pathological basis for Apert syndrome. Am. J. Hum. Genet. 1999,64 (2), 446-61.

77. Ferlini, A.; Galie, N.; Merlini, L.; Sewry, C.; Branzi, A.; Muntoni, F., A novel Alu-like element rearranged in the dystrophin gene causes a splicing mutation in a family with X-linked dilated cardiomyopathy. Am. J. Hum. Genet. 1998,63 (2), 436-46.

78. McNaughton, J. C.; Broom, J. E.; Hill, D. F.; Jones, W. A.; Marshall, C. J.; Renwick, N. M.; Stockwell, P. A.; Petersen, G. B., A cluster of transposon-like repetitive sequences in intron 7 of the human dystrophin gene. J. Mol. Biol. 1993,232 (1), 314-21.

79. Musova, Z.; Hedvicakova, P.; Mohrmann, M.; Tesarova, M.; Krepelova, A.; Zeman, J.; Sedlacek, Z., A novel insertion of a rearranged L1 element in exon 44 of the dystrophin gene: further evidence for possible bias in retroposon integration. Biochem.Biophys.Res. Commun.2006,347 (1), 145-9.

80. Pizzuti, A.; Pieretti, M.; Fenwick, R. G.; Gibbs, R. A.; Caskey, C. T., A transposon-like element in the deletion-prone region of the dystrophin gene. Genomics 1992,13 (3), 594-600.

81. Narita, N.; Nishio, H.; Kitoh, Y.; Ishikawa, Y.; Minami, R.; Nakamura, H.; Matsuo, M., Insertion of a 5' truncated L1 element into the 3' end of exon 44 of the dystrophin gene resulted in skipping of the exon during splicing in a case of Duchenne muscular dystrophy. J. Clin. Invest. 1993,91 (5), 1862-7.

82. Mine, M.; Chen, J. M.; Brivet, M.; Desguerre, I.; Marchant, D.; de Lonlay, P.; Bernard, A.; Ferec, C.; Abitbol, M.; Ricquier, D.; Marsac, C., A large genomic deletion in the PDHX gene caused by the retrotranspositional insertion of a full-length LINE-1 element. Hum. Mutat. 2007,28 (2), 137-42.

83. Ast, G., How did alternative splicing evolve? Nat. Rev. Genet. 2004,5 (10), 773-82.

84. Miki, Y.; Katagiri, T.; Kasumi, F.; Yoshimoto, T.; Nakamura, Y., Mutation analysis in the BRCA2 gene in primary breast cancers. Nat. Genet. 1996,13 (2), 245-7. 
85. Ricci, V.; Regis, S.; Di Duca, M.; Filocamo, M., An Alu-mediated rearrangement as cause of exon skipping in Hunter disease. Hum. Genet.2003,112 (4), 419-25.

86. Gallus, G. N.; Cardaioli, E.; Rufa, A.; Da Pozzo, P.; Bianchi, S.; D'Eramo, C.; Collura, M.; Tumino, M.; Pavone, L.; Federico, A., Alu-element insertion in an OPA1 intron sequence associated with autosomal dominant optic atrophy. Mol. Vision 2010,16, 17883.

87. Kondo-Iida, E.; Kobayashi, K.; Watanabe, M.; Sasaki, J.; Kumagai, T.; Koide, H.; Saito, K.; Osawa, M.; Nakamura, Y.; Toda, T., Novel mutations and genotypephenotype relationships in 107 families with Fukuyama-type congenital muscular dystrophy (FCMD). Hum. Mol. Genet.1999,8 (12), 2303-9.

88. Schwahn, U.; Lenzner, S.; Dong, J.; Feil, S.; Hinzmann, B.; van Duijnhoven, G.; Kirschner, R.; Hemberger, M.; Bergen, A. A.; Rosenberg, T.; Pinckers, A. J.; Fundele, R.; Rosenthal, A.; Cremers, F. P.; Ropers, H. H.; Berger, W., Positional cloning of the gene for X-linked retinitis pigmentosa 2. Nat. Genet.1998,19 (4), 327-32.

89. Bourque, G.; Leong, B.; Vega, V. B.; Chen, X.; Lee, Y. L.; Srinivasan, K. G.; Chew, J. L.; Ruan, Y.; Wei, C. L.; Ng, H. H.; Liu, E. T., Evolution of the mammalian transcription factor binding repertoire via transposable elements. Genome Res. 2008,18 (11), 1752-62.

90. Cohen, C. J.; Lock, W. M.; Mager, D. L., Endogenous retroviral LTRs as promoters for human genes: a critical assessment. Gene 2009,448 (2), 105-14.

91. Teng, L.; Firpi, H. A.; Tan, K., Enhancers in embryonic stem cells are enriched for transposable elements and genetic variations associated with cancers. Nucleic Acids Res. 2011,39 (17), 7371-9.

92. Wang, T.; Zeng, J.; Lowe, C. B.; Sellers, R. G.; Salama, S. R.; Yang, M.; Burgess, S. M.; Brachmann, R. K.; Haussler, D., Species-specific endogenous retroviruses shape the transcriptional network of the human tumor suppressor protein p53.Proc. Natl. Acad. Sci. U. S. A.2007,104 (47), 18613-8.

93. Jordan, I. K.; Rogozin, I. B.; Glazko, G. V.; Koonin, E. V., Origin of a substantial fraction of human regulatory sequences from transposable elements. Trends Genet.2003,19 (2), 68-72.

94. Bejerano, G.; Lowe, C. B.; Ahituv, N.; King, B.; Siepel, A.; Salama, S. R.; Rubin, E. M.; Kent, W. J.; Haussler, D., A distal enhancer and an ultraconserved exon are derived from a novel retroposon. Nature 2006,441 (7089), 87-90.

95. Johnson, R.; Gamblin, R. J.; Ooi, L.; Bruce, A. W.; Donaldson, I. J.; Westhead, D. R.; Wood, I. C.; Jackson, R. M.; Buckley, N. J., Identification of the REST regulon reveals extensive transposable element-mediated binding site duplication. Nucleic Acids Res.2006,34 (14), 3862-77.

96. Laperriere, D.; Wang, T. T.; White, J. H.; Mader, S., Widespread Alu repeat-driven expansion of consensus DR2 retinoic acid response elements during primate evolution. BMC Genomics 2007,8, 23.

97. Polak, P.; Domany, E., Alu elements contain many binding sites for transcription factors and may play a role in regulation of developmental processes. BMC Genomics 2006,7, 133.

98. Santangelo, A. M.; de Souza, F. S.; Franchini, L. F.; Bumaschny, V. F.; Low, M. J.; Rubinstein, M., Ancient exaptation of a CORE-SINE retroposon into a highly conserved mammalian neuronal enhancer of the proopiomelanocortin gene. PLoS Genet.2007,3 (10), 1813-26.

99. Chuong, E. B., Retroviruses facilitate the rapid evolution of the mammalian placenta. BioEssays 2013,35 (10), 853-61. 
100. Dupressoir, A.; Lavialle, C.; Heidmann, T., From ancestral infectious retroviruses to bona fide cellular genes: role of the captured syncytins in placentation. Placenta 2012,33 (9), 663-71.

101. Esnault, C.; Cornelis, G.; Heidmann, O.; Heidmann, T., Differential evolutionary fate of an ancestral primate endogenous retrovirus envelope gene, the EnvV syncytin, captured for a function in placentation. PLoS Genet. 2013,9 (3), e1003400.

102. Lokossou, A. G.; Toudic, C.; Barbeau, B., Implication of human endogenous retrovirus envelope proteins in placental functions. Viruses 2014,6 (11), 4609-27.

103. Mi, S.; Lee, X.; Li, X.; Veldman, G. M.; Finnerty, H.; Racie, L.; LaVallie, E.; Tang, X. Y.; Edouard, P.; Howes, S.; Keith, J. C., Jr.; McCoy, J. M., Syncytin is a captive retroviral envelope protein involved in human placental morphogenesis. Nature 2000,403 (6771), 785-9.

104. Dupressoir, A.; Vernochet, C.; Bawa, O.; Harper, F.; Pierron, G.; Opolon, P.; Heidmann, T., Syncytin-A knockout mice demonstrate the critical role in placentation of a fusogenic, endogenous retrovirus-derived, envelope gene. Proc. Natl. Acad. Sci. U. S. A. 2009,106 (29), 12127-32.

105. Landry, J. R.; Rouhi, A.; Medstrand, P.; Mager, D. L., The Opitz syndrome gene Mid1 is transcribed from a human endogenous retroviral promoter. Mol. Biol. Evol. 2002,19 (11), 1934-42.

106. Landry, J. R.; Mager, D. L., Widely spaced alternative promoters, conserved between human and rodent, control expression of the Opitz syndrome gene MID1. Genomics 2002,80 (5), 499-508.

107. Fontanella, B.; Russolillo, G.; Meroni, G., MID1 mutations in patients with X-linked Opitz G/BBB syndrome. Hum. Mutat. 2008,29 (5), 584-94.

108. Than, N. G.; Romero, R.; Xu, Y.; Erez, O.; Xu, Z.; Bhatti, G.; Leavitt, R.; Chung, T. H.; El-Azzamy, H.; LaJeunesse, C.; Wang, B.; Balogh, A.; Szalai, G.; Land, S.; Dong, Z.; Hassan, S. S.; Chaiworapongsa, T.; Krispin, M.; Kim, C. J.; Tarca, A. L.; Papp, Z.; Bohn, H., Evolutionary origins of the placental expression of chromosome 19 cluster galectins and their complex dysregulation in preeclampsia. Placenta 2014.

109. Taube, J. H.; Allton, K.; Duncan, S. A.; Shen, L.; Barton, M. C., Foxa1 functions as a pioneer transcription factor at transposable elements to activate Afp during differentiation of embryonic stem cells. J. Biol. Chem.2010,285 (21), 16135-44.

110. Chatterjee, R.; Vinson, C., CpG methylation recruits sequence specific transcription factors essential for tissue specific gene expression. Biochim. Biophys. Acta 2012.

111. Reiss, D.; Zhang, Y.; Rouhi, A.; Reuter, M.; Mager, D. L., Variable DNA methylation of transposable elements: the case study of mouse Early Transposons. Epigenetics 2010,5 (1), 68-79.

112. Slotkin, R. K.; Martienssen, R., Transposable elements and the epigenetic regulation of the genome. Nat. Rev. Genet.2007,8 (4), 272-85.

113. Renfree, M. B.; Suzuki, S.; Kaneko-Ishino, T., The origin and evolution of genomic imprinting and viviparity in mammals. Philosoph. Transact. Royal Society London, Biol.Sci.2013,368 (1609), 20120151.

114. Emera, D.; Wagner, G. P., Transposable element recruitments in the mammalian placenta: impacts and mechanisms. Brief.Function. Genomics 2012,11 (4), 267-76.

115. Haig, D., Retroviruses and the placenta. Current biology : $C B$ 2012,22 (15), R609-13.

116. Fujimoto, R.; Sasaki, T.; Kudoh, H.; Taylor, J. M.; Kakutani, T.; Dennis, E. S., Epigenetic variation in the FWA gene within the genus Arabidopsis. Plant J.2011,66 (5), 831-43.

117. Lippman, Z.; Gendrel, A. V.; Black, M.; Vaughn, M. W.; Dedhia, N.; McCombie, W. R.; Lavine, K.; Mittal, V.; May, B.; Kasschau, K. D.; Carrington, J. C.; Doerge, R. W.; 
Colot, V.; Martienssen, R., Role of transposable elements in heterochromatin and epigenetic control. Nature 2004,430 (6998), 471-6.

118. Ross, J. P.; Rand, K. N.; Molloy, P. L., Hypomethylation of repeated DNA sequences in cancer. Epigenomics 2010,2 (2), 245-69.

119. Watanabe, Y.; Maekawa, M., Methylation of DNA in cancer. Adv. Clin. Chem. 2010,52, 145-67.

120. Kulis, M.; Queiros, A. C.; Beekman, R.; Martin-Subero, J. I., Intragenic DNA methylation in transcriptional regulation, normal differentiation and cancer. Biochim. Biophys Acta 2013,1829 (11), 1161-74.

121. Seisenberger, S.; Popp, C.; Reik, W., Retrotransposons and germ cells: reproduction, death, and diversity. F1000 Biol. Rep. 2010,2.

122. Kano, H.; Godoy, I.; Courtney, C.; Vetter, M. R.; Gerton, G. L.; Ostertag, E. M.; Kazazian, H. H., Jr., L1 retrotransposition occurs mainly in embryogenesis and creates somatic mosaicism. Genes Dev. 2009,23 (11), 1303-12.

123. Lane, N.; Dean, W.; Erhardt, S.; Hajkova, P.; Surani, A.; Walter, J.; Reik, W., Resistance of IAPs to methylation reprogramming may provide a mechanism for epigenetic inheritance in the mouse. Genesis 2003,35 (2), 88-93.

124. Whitelaw, E.; Martin, D. I., Retrotransposons as epigenetic mediators of phenotypic variation in mammals. Nat. Genet. 2001,27 (4), 361-5.

125. Wilson, A. S.; Power, B. E.; Molloy, P. L., DNA hypomethylation and human diseases. Biochim. Biophys. Acta 2007,1775 (1), 138-62.

126. Iskow, R. C.; McCabe, M. T.; Mills, R. E.; Torene, S.; Pittard, W. S.; Neuwald, A. F.; Van Meir, E. G.; Vertino, P. M.; Devine, S. E., Natural mutagenesis of human genomes by endogenous retrotransposons. Cell 2010,141 (7), 1253-61.

127. Lee, E.; Iskow, R.; Yang, L.; Gokcumen, O.; Haseley, P.; Luquette, L. J., 3rd; Lohr, J. G.; Harris, C. C.; Ding, L.; Wilson, R. K.; Wheeler, D. A.; Gibbs, R. A.; Kucherlapati, R.; Lee, C.; Kharchenko, P. V.; Park, P. J., Landscape of Somatic Retrotransposition in Human Cancers. Science 2012.

128. Ferreira, P. G.; Jares, P.; Rico, D.; Gomez-Lopez, G.; Martinez-Trillos, A.; Villamor, N.; Ecker, S.; Gonzalez-Perez, A.; Knowles, D. G.; Monlong, J.; Johnson, R.; Quesada, V.; Djebali, S.; Papasaikas, P.; Lopez-Guerra, M.; Colomer, D.; Royo, C.; Cazorla, M.; Pinyol, M.; Clot, G.; Aymerich, M.; Rozman, M.; Kulis, M.; Tamborero, D.; Gouin, A.; Blanc, J.; Gut, M.; Gut, I.; Puente, X. S.; Pisano, D. G.; Martin-Subero, J. I.; LopezBigas, N.; Lopez-Guillermo, A.; Valencia, A.; Lopez-Otin, C.; Campo, E.; Guigo, R., Transcriptome characterization by RNA sequencing identifies a major molecular and clinical subdivision in chronic lymphocytic leukemia. Genome Res.2014,24 (2), 212-26.

129. Tubio, J. M.; Li, Y.; Ju, Y. S.; Martincorena, I.; Cooke, S. L.; Tojo, M.; Gundem, G.; Pipinikas, C. P.; Zamora, J.; Raine, K.; Menzies, A.; Roman-Garcia, P.; Fullam, A.; Gerstung, M.; Shlien, A.; Tarpey, P. S.; Papaemmanuil, E.; Knappskog, S.; Van Loo, P.; Ramakrishna, M.; Davies, H. R.; Marshall, J.; Wedge, D. C.; Teague, J. W.; Butler, A. P.; Nik-Zainal, S.; Alexandrov, L.; Behjati, S.; Yates, L. R.; Bolli, N.; Mudie, L.; Hardy, C.; Martin, S.; McLaren, S.; O'Meara, S.; Anderson, E.; Maddison, M.; Gamble, S.; Foster, C.; Warren, A. Y.; Whitaker, H.; Brewer, D.; Eeles, R.; Cooper, C.; Neal, D.; Lynch, A. G.; Visakorpi, T.; Isaacs, W. B.; van't Veer, L.; Caldas, C.; Desmedt, C.; Sotiriou, C.; Aparicio, S.; Foekens, J. A.; Eyfjord, J. E.; Lakhani, S. R.; Thomas, G.; Myklebost, O.; Span, P. N.; Borresen-Dale, A. L.; Richardson, A. L.; Van de Vijver, M.; Vincent-Salomon, A.; Van den Eynden, G. G.; Flanagan, A. M.; Futreal, P. A.; Janes, S. M.; Bova, G. S.; Stratton, M. R.; McDermott, U.; Campbell, P. J., Mobile DNA in cancer. Extensive transduction of nonrepetitive DNA mediated by L1 retrotransposition in cancer genomes. Science 2014,345 (6196), 1251343. 
130. Florl, A. R.; Steinhoff, C.; Muller, M.; Seifert, H. H.; Hader, C.; Engers, R.; Ackermann, R.; Schulz, W. A., Coordinate hypermethylation at specific genes in prostate carcinoma precedes LINE-1 hypomethylation. Brit. J. Cancer 2004,91 (5), 98594.

131. Kim, M. J.; White-Cross, J. A.; Shen, L.; Issa, J. P.; Rashid, A., Hypomethylation of long interspersed nuclear element-1 in hepatocellular carcinomas. Modern Pathol.2009,22 (3), 442-9.

132. Suter, C. M.; Martin, D. I.; Ward, R. L., Hypomethylation of L1 retrotransposons in colorectal cancer and adjacent normal tissue. Int. J. Colorectal Dis.2004,19 (2), 95-101.

133. Santourlidis, S.; Florl, A.; Ackermann, R.; Wirtz, H. C.; Schulz, W. A., High frequency of alterations in DNA methylation in adenocarcinoma of the prostate. Prostate 1999,39 (3), 166-74.

134. Yegnasubramanian, S.; Haffner, M. C.; Zhang, Y.; Gurel, B.; Cornish, T. C.; Wu, Z.; Irizarry, R. A.; Morgan, J.; Hicks, J.; DeWeese, T. L.; Isaacs, W. B.; Bova, G. S.; De Marzo, A. M.; Nelson, W. G., DNA hypomethylation arises later in prostate cancer progression than $\mathrm{CpG}$ island hypermethylation and contributes to metastatic tumor heterogeneity. Cancer Res. 2008,68 (21), 8954-67.

135. Ecsedi, S. I.; Hernandez-Vargas, H.; Lima, S. C.; Herceg, Z.; Adany, R.; Balazs, M., Transposable hypomethylation is associated with metastatic capacity of primary melanomas. Int.J.Clin.Exp. Pathol.2013,6 (12), 2943-8.

136. Lanikova, L.; Kucerova, J.; Indrak, K.; Divoka, M.; Issa, J. P.; Papayannopoulou, T.; Prchal, J. T.; Divoky, V., beta-Thalassemia due to intronic LINE-1 insertion in the betaglobin gene (HBB): molecular mechanisms underlying reduced transcript levels of the beta-globin(L1) allele. Hum. Mutat.2013,34 (10), 1361-5.

137. Saito, K.; Siomi, M. C., Small RNA-mediated quiescence of transposable elements in animals. Dev. Cell 2010,19 (5), 687-97.

138. Lu, J.; Getz, G.; Miska, E. A.; Alvarez-Saavedra, E.; Lamb, J.; Peck, D.; SweetCordero, A.; Ebert, B. L.; Mak, R. H.; Ferrando, A. A.; Downing, J. R.; Jacks, T.; Horvitz, H. R.; Golub, T. R., MicroRNA expression profiles classify human cancers. Nature 2005,435 (7043), 834-8.

139. Jung, S.; Ro, S. W.; Jung, G.; Ju, H. L.; Yu, E. S.; Son, W. C., Sleeping Beauty transposon system harboring HRAS, c-Myc and shp53 induces sarcomatoid carcinomas in mouse skin. Oncol. Reports 2013,29 (4), 1293-8.

140. Wong, C. C.; Martincorena, I.; Rust, A. G.; Rashid, M.; Alifrangis, C.; Alexandrov, L. B.; Tiffen, J. C.; Kober, C.; Green, A. R.; Massie, C. E.; Nangalia, J.; Lempidaki, S.; Dohner, H.; Dohner, K.; Bray, S. J.; McDermott, U.; Papaemmanuil, E.; Campbell, P. J.; Adams, D. J., Inactivating CUX1 mutations promote tumorigenesis. Nat. Genet.2014,46 (1), 33-8.

141. Dupuy, A. J., Transposon-based screens for cancer gene discovery in mouse models. Semin. Cancer Biol. 2010,20 (4), 261-8.

142. Friedel, R. H.; Friedel, C. C.; Bonfert, T.; Shi, R.; Rad, R.; Soriano, P., Clonal expansion analysis of transposon insertions by high-throughput sequencing identifies candidate cancer genes in a PiggyBac mutagenesis screen. PloS One 2013,8 (8), e72338.

143. Quintana, R. M.; Dupuy, A. J.; Bravo, A.; Casanova, M. L.; Alameda, J. P.; Page, A.; Sanchez-Viera, M.; Ramirez, A.; Navarro, M., A transposon-based analysis of gene mutations related to skin cancer development. J. Invest. Dermatol.2013,133 (1), 239-48.

144. Takeda, H.; Wei, Z.; Koso, H.; Rust, A. G.; Yew, C. C.; Mann, M. B.; Ward, J. M.; Adams, D. J.; Copeland, N. G.; Jenkins, N. A., Transposon mutagenesis identifies genes 
and evolutionary forces driving gastrointestinal tract tumor progression. Nat. Genet.2015,47 (2), 142-50.

145. Koso, H.; Takeda, H.; Yew, C. C.; Ward, J. M.; Nariai, N.; Ueno, K.; Nagasaki, M.; Watanabe, S.; Rust, A. G.; Adams, D. J.; Copeland, N. G.; Jenkins, N. A., Transposon mutagenesis identifies genes that transform neural stem cells into glioma-initiating cells.Proc. Natl. Acad. Sci. U. S. A.2012,109 (44), E2998-3007.

146. Mann, K. M.; Ward, J. M.; Yew, C. C.; Kovochich, A.; Dawson, D. W.; Black, M. A.; Brett, B. T.; Sheetz, T. E.; Dupuy, A. J.; Chang, D. K.; Biankin, A. V.; Waddell, N.; Kassahn, K. S.; Grimmond, S. M.; Rust, A. G.; Adams, D. J.; Jenkins, N. A.; Copeland, N. G., Sleeping Beauty mutagenesis reveals cooperating mutations and pathways in pancreatic adenocarcinoma.Proc. Natl. Acad. Sci. U. S. A.2012,109 (16), 5934-41.

147. Wong, S. M.; Bernui, M.; Shen, H.; Akerley, B. J., Genome-wide fitness profiling reveals adaptations required by Haemophilus in coinfection with influenza A virus in the murine lung.Proc. Natl. Acad. Sci. U. S. A.2013,110 (38), 15413-8.

148. Lin, T.; Troy, E. B.; Hu, L. T.; Gao, L.; Norris, S. J., Transposon mutagenesis as an approach to improved understanding of Borrelia pathogenesis and biology. Front.Cell. Infect.Microbiol.2014,4, 63.

149. Shah, D. H.; Zhou, X.; Kim, H. Y.; Call, D. R.; Guard, J., Transposon mutagenesis of Salmonella enterica serovar Enteritidis identifies genes that contribute to invasiveness in human and chicken cells and survival in egg albumen. Infect.Immun.2012,80 (12), 4203-15.

150. Ding, Y.; Liu, W.; Deng, Y.; Jomok, B.; Yang, J.; Huang, W.; Clark, K. J.; Zhong, T. P.; Lin, X.; Ekker, S. C.; Xu, X., Trapping cardiac recessive mutants via expressionbased insertional mutagenesis screening. Circulation Res.2013,112 (4), 606-17.

151. Chénais, B., Vectors for gene therapy: A place for DNA transposon. Open J. Genet.2013,03 (02), 1-11.

152. Hackett, P. B.; Largaespada, D. A.; Switzer, K. C.; Cooper, L. J., Evaluating risks of insertional mutagenesis by DNA transposons in gene therapy. Translational Res.2013,161 (4), 265-83.

153. Ohlfest, J. R.; Demorest, Z. L.; Motooka, Y.; Vengco, I.; Oh, S.; Chen, E.; Scappaticci, F. A.; Saplis, R. J.; Ekker, S. C.; Low, W. C.; Freese, A. B.; Largaespada, D. A., Combinatorial antiangiogenic gene therapy by nonviral gene transfer using the sleeping beauty transposon causes tumor regression and improves survival in mice bearing intracranial human glioblastoma. Mol. Ther.2005,12 (5), 778-88.

154. Kang, Y.; Zhang, X.; Jiang, W.; Wu, C.; Chen, C.; Zheng, Y.; Gu, J.; Xu, C., Tumordirected gene therapy in mice using a composite nonviral gene delivery system consisting of the piggyBac transposon and polyethylenimine. BMC Cancer 2009,9, 126.

155. Kang, Y.; Zhang, X. Y.; Jiang, W.; Wu, C. Q.; Chen, C. M.; Gu, J. R.; Zheng, Y. F.; $\mathrm{Xu}, \mathrm{C}$. J., The piggyBac transposon is an integrating non-viral gene transfer vector that enhances the efficiency of GDEPT. Cell Biol.Int.2009,33 (4), 509-15.

156. Hollis, R. P.; Nightingale, S. J.; Wang, X.; Pepper, K. A.; Yu, X. J.; Barsky, L.; Crooks, G. M.; Kohn, D. B., Stable gene transfer to human CD34(+) hematopoietic cells using the Sleeping Beauty transposon. Exp. Hematol.2006,34 (10), 1333-43.

157. Izsvak, Z.; Chuah, M. K.; Vandendriessche, T.; Ivics, Z., Efficient stable gene transfer into human cells by the Sleeping Beauty transposon vectors. Methods 2009,49 (3), 28797.

158. Mates, L.; Chuah, M. K.; Belay, E.; Jerchow, B.; Manoj, N.; Acosta-Sanchez, A.; Grzela, D. P.; Schmitt, A.; Becker, K.; Matrai, J.; Ma, L.; Samara-Kuko, E.; Gysemans, C.; Pryputniewicz, D.; Miskey, C.; Fletcher, B.; VandenDriessche, T.; Ivics, Z.; Izsvak, 
Z., Molecular evolution of a novel hyperactive Sleeping Beauty transposase enables robust stable gene transfer in vertebrates. Nat. Genet.2009,41 (6), 753-61.

159. Sumiyoshi, T.; Holt, N. G.; Hollis, R. P.; Ge, S.; Cannon, P. M.; Crooks, G. M.; Kohn, D. B., Stable transgene expression in primitive human CD34+ hematopoietic stem/progenitor cells, using the Sleeping Beauty transposon system. Hum. Gene Ther.2009,20 (12), 1607-26.

160. Xue, X.; Huang, X.; Nodland, S. E.; Mates, L.; Ma, L.; Izsvak, Z.; Ivics, Z.; LeBien, T. W.; McIvor, R. S.; Wagner, J. E.; Zhou, X., Stable gene transfer and expression in cord blood-derived CD34+ hematopoietic stem and progenitor cells by a hyperactive Sleeping Beauty transposon system. Blood 2009,114 (7), 1319-30.

161. Huang, G.; Yu, L.; Cooper, L. J.; Hollomon, M.; Huls, H.; Kleinerman, E. S., Genetically modified $\mathrm{T}$ cells targeting interleukin-11 receptor alpha-chain kill human osteosarcoma cells and induce the regression of established osteosarcoma lung metastases. Cancer Res.2012,72 (1), 271-81.

162. Huang, X.; Guo, H.; Tammana, S.; Jung, Y. C.; Mellgren, E.; Bassi, P.; Cao, Q.; Tu, Z. J.; Kim, Y. C.; Ekker, S. C.; Wu, X.; Wang, S. M.; Zhou, X., Gene transfer efficiency and genome-wide integration profiling of Sleeping Beauty, Tol2, and piggyBac transposons in human primary T cells. Mol. Ther.2010,18 (10), 1803-13.

163. Huang, X.; Wilber, A.; McIvor, R. S.; Zhou, X., DNA transposons for modification of human primary T lymphocytes. Methods Mol. Biol.2009,506, 115-26.

164. Manuri, P. V.; Wilson, M. H.; Maiti, S. N.; Mi, T.; Singh, H.; Olivares, S.; Dawson, M. J.; Huls, H.; Lee, D. A.; Rao, P. H.; Kaminski, J. M.; Nakazawa, Y.; Gottschalk, S.; Kebriaei, P.; Shpall, E. J.; Champlin, R. E.; Cooper, L. J., piggyBac transposon/transposase system to generate CD19-specific T cells for the treatment of Blineage malignancies. Hum. Gene Ther.2010,21 (4), 427-37.

165. Nakazawa, Y.; Huye, L. E.; Dotti, G.; Foster, A. E.; Vera, J. F.; Manuri, P. R.; June, C. H.; Rooney, C. M.; Wilson, M. H., Optimization of the PiggyBac transposon system for the sustained genetic modification of human T lymphocytes. J. Immunother.2009,32 (8), 826-36.

166. Nakazawa, Y.; Huye, L. E.; Salsman, V. S.; Leen, A. M.; Ahmed, N.; Rollins, L.; Dotti, G.; Gottschalk, S. M.; Wilson, M. H.; Rooney, C. M., PiggyBac-mediated cancer immunotherapy using EBV-specific cytotoxic T-cells expressing HER2-specific chimeric antigen receptor. Mol. Ther.2011,19 (12), 2133-43.

167. Singh, H.; Manuri, P. R.; Olivares, S.; Dara, N.; Dawson, M. J.; Huls, H.; Hackett, P. B.; Kohn, D. B.; Shpall, E. J.; Champlin, R. E.; Cooper, L. J., Redirecting specificity of T-cell populations for CD19 using the Sleeping Beauty system. Cancer Res.2008,68 (8), 2961-71.

168. Orban, T. I.; Apati, A.; Nemeth, A.; Varga, N.; Krizsik, V.; Schamberger, A.; Szebenyi, K.; Erdei, Z.; Varady, G.; Karaszi, E.; Homolya, L.; Nemet, K.; Gocza, E.; Miskey, C.; Mates, L.; Ivics, Z.; Izsvak, Z.; Sarkadi, B., Applying a "double-feature" promoter to identify cardiomyocytes differentiated from human embryonic stem cells following transposon-based gene delivery. Stem Cells 2009,27 (5), 1077-87.

169. Wilber, A.; Linehan, J. L.; Tian, X.; Woll, P. S.; Morris, J. K.; Belur, L. R.; McIvor, R. S.; Kaufman, D. S., Efficient and stable transgene expression in human embryonic stem cells using transposon-mediated gene transfer. Stem Cells 2007,25 (11), 2919-27.

170. Jena, B.; Dotti, G.; Cooper, L. J., Redirecting T-cell specificity by introducing a tumorspecific chimeric antigen receptor. Blood 2010,116 (7), 1035-44.

171. Torikai, H.; Reik, A.; Liu, P. Q.; Zhou, Y.; Zhang, L.; Maiti, S.; Huls, H.; Miller, J. C.; Kebriaei, P.; Rabinovitch, B.; Lee, D. A.; Champlin, R. E.; Bonini, C.; Naldini, L.; Rebar, E. J.; Gregory, P. D.; Holmes, M. C.; Cooper, L. J., A foundation for universal 
T-cell based immunotherapy: T cells engineered to express a CD19-specific chimericantigen-receptor and eliminate expression of endogenous TCR. Blood 2012,119 (24), 5697-705.

172. Singh, H.; Figliola, M. J.; Dawson, M. J.; Olivares, S.; Zhang, L.; Yang, G.; Maiti, S.; Manuri, P.; Senyukov, V.; Jena, B.; Kebriaei, P.; Champlin, R. E.; Huls, H.; Cooper, L. J., Manufacture of clinical-grade CD19-specific T cells stably expressing chimeric antigen receptor using Sleeping Beauty system and artificial antigen presenting cells. PloS One 2013,8 (5), e64138.

173. Kren, B. T.; Unger, G. M.; Sjeklocha, L.; Trossen, A. A.; Korman, V.; Diethelm-Okita, B. M.; Reding, M. T.; Steer, C. J., Nanocapsule-delivered Sleeping Beauty mediates therapeutic Factor VIII expression in liver sinusoidal endothelial cells of hemophilia A mice. J. Clin. Invest.2009,119 (7), 2086-99.

174. Liu, L.; Mah, C.; Fletcher, B. S., Sustained FVIII expression and phenotypic correction of hemophilia A in neonatal mice using an endothelial-targeted sleeping beauty transposon. Mol. Ther.2006,13 (5), 1006-15.

175. Ohlfest, J. R.; Frandsen, J. L.; Fritz, S.; Lobitz, P. D.; Perkinson, S. G.; Clark, K. J.; Nelsestuen, G.; Key, N. S.; McIvor, R. S.; Hackett, P. B.; Largaespada, D. A., Phenotypic correction and long-term expression of factor VIII in hemophilic mice by immunotolerization and nonviral gene transfer using the Sleeping Beauty transposon system. Blood 2005,105 (7), 2691-8.

176. Yant, S. R.; Meuse, L.; Chiu, W.; Ivics, Z.; Izsvak, Z.; Kay, M. A., Somatic integration and long-term transgene expression in normal and haemophilic mice using a DNA transposon system. Nat. Genet.2000,25 (1), 35-41.

177. Montini, E.; Held, P. K.; Noll, M.; Morcinek, N.; Al-Dhalimy, M.; Finegold, M.; Yant, S. R.; Kay, M. A.; Grompe, M., In vivo correction of murine tyrosinemia type I by DNA-mediated transposition. Mol. Ther.2002,6 (6), 759-69.

178. Ortiz-Urda, S.; Lin, Q.; Yant, S. R.; Keene, D.; Kay, M. A.; Khavari, P. A., Sustainable correction of junctional epidermolysis bullosa via transposon-mediated nonviral gene transfer. Gene Ther.2003,10 (13), 1099-104.

179. Liu, L.; Liu, H.; Visner, G.; Fletcher, B. S., Sleeping Beauty-mediated eNOS gene therapy attenuates monocrotaline-induced pulmonary hypertension in rats. FASEB $J$. 2006,20 (14), 2594-6.

180. Liu, H.; Liu, L.; Fletcher, B. S.; Visner, G. A., Sleeping Beauty-based gene therapy with indoleamine 2,3-dioxygenase inhibits lung allograft fibrosis. FASEB J. 2006,20 (13), 2384-6.

181. Aronovich, E. L.; Bell, J. B.; Belur, L. R.; Gunther, R.; Koniar, B.; Erickson, D. C.; Schachern, P. A.; Matise, I.; McIvor, R. S.; Whitley, C. B.; Hackett, P. B., Prolonged expression of a lysosomal enzyme in mouse liver after Sleeping Beauty transposonmediated gene delivery: implications for non-viral gene therapy of mucopolysaccharidoses. J. Gene Med.2007,9 (5), 403-15.

182. Aronovich, E. L.; Bell, J. B.; Khan, S. A.; Belur, L. R.; Gunther, R.; Koniar, B.; Schachern, P. A.; Parker, J. B.; Carlson, C. S.; Whitley, C. B.; McIvor, R. S.; Gupta, P.; Hackett, P. B., Systemic correction of storage disease in MPS I NOD/SCID mice using the sleeping beauty transposon system. Mol. Ther.2009,17 (7), 1136-44.

183. Wang, X.; Sarkar, D. P.; Mani, P.; Steer, C. J.; Chen, Y.; Guha, C.; Chandrasekhar, V.; Chaudhuri, A.; Roy-Chowdhury, N.; Kren, B. T.; Roy-Chowdhury, J., Long-term reduction of jaundice in Gunn rats by nonviral liver-targeted delivery of Sleeping Beauty transposon. Hepatology 2009,50 (3), 815-24.

184. Huang, X.; Guo, H.; Kang, J.; Choi, S.; Zhou, T. C.; Tammana, S.; Lees, C. J.; Li, Z. Z.; Milone, M.; Levine, B. L.; Tolar, J.; June, C. H.; Scott McIvor, R.; Wagner, J. E.; 
Blazar, B. R.; Zhou, X., Sleeping Beauty transposon-mediated engineering of human primary T cells for therapy of CD19+ lymphoid malignancies. Mol. Ther.2008,16 (3), 580-9.

185. Singh, H.; Figliola, M. J.; Dawson, M. J.; Huls, H.; Olivares, S.; Switzer, K.; Mi, T.; Maiti, S.; Kebriaei, P.; Lee, D. A.; Champlin, R. E.; Cooper, L. J., Reprogramming CD19-specific T cells with IL-21 signaling can improve adoptive immunotherapy of Blineage malignancies. Cancer Res.2011,71 (10), 3516-27.

186. Hyland, K. A.; Olson, E. R.; Clark, K. J.; Aronovich, E. L.; Hackett, P. B.; Blazar, B. R.; Tolar, J.; Scott McIvor, R., Sleeping Beauty-mediated correction of Fanconi anemia type C. J. Gene Med.2011,13 (9), 462-9.

187. Staunstrup, N. H.; Madsen, J.; Primo, M. N.; Li, J.; Liu, Y.; Kragh, P. M.; Li, R.; Schmidt, M.; Purup, S.; Dagnaes-Hansen, F.; Svensson, L.; Petersen, T. K.; Callesen, H.; Bolund, L.; Mikkelsen, J. G., Development of transgenic cloned pig models of skin inflammation by DNA transposon-directed ectopic expression of human beta1 and alpha2 integrin. PloS One 2012,7 (5), e36658.

188. Xiao, J.; Meng, X. M.; Huang, X. R.; Chung, A. C.; Feng, Y. L.; Hui, D. S.; Yu, C. M.; Sung, J. J.; Lan, H. Y., miR-29 inhibits bleomycin-induced pulmonary fibrosis in mice. Mol. Ther.2012,20 (6), 1251-60.

189. Friedl, A. A.; Kiechle, M.; Maxeiner, H. G.; Schiestl, R. H.; Eckardt-Schupp, F., Ty1 integrase overexpression leads to integration of non-Ty1 DNA fragments into the genome of Saccharomyces cerevisiae. Mol. Genet. Genomics2010,284 (4), 231-42.

190. Mularoni, L.; Zhou, Y.; Bowen, T.; Gangadharan, S.; Wheelan, S. J.; Boeke, J. D., Retrotransposon Ty1 integration targets specifically positioned asymmetric nucleosomal DNA segments in tRNA hotspots. Genome Res.2012,22 (4), 693-703.

191. Waddell, C. S.; Craig, N. L., Tn7 transposition: two transposition pathways directed by five Tn7-encoded genes. Genes Dev.1988,2 (2), 137-49.

192. Wolkow, C. A.; DeBoy, R. T.; Craig, N. L., Conjugating plasmids are preferred targets for Tn7. Genes Dev.1996,10 (17), 2145-57.

193. Mitra, R.; McKenzie, G. J.; Yi, L.; Lee, C. A.; Craig, N. L., Characterization of the TnsD-attTn7 complex that promotes site-specific insertion of Tn7. Mobile DNA 2010,1 $(1), 18$.

194. Choi, K. H.; Kim, K. J., Applications of transposon-based gene delivery system in bacteria. J.Microbiol. Biotechnol.2009,19 (3), 217-28.

195. Kuduvalli, P. N.; Mitra, R.; Craig, N. L., Site-specific Tn7 transposition into the human genome. Nucleic Acids Res.2005,33 (3), 857-63. 